\title{
ARTIKKELIT
}

\section{ע Viisauden piirteiden ilmentymät ikääntyneiden tietotyöläisten mediasuhteissa}

\author{
Timo Cornér ${ }^{1}$
}

\author{
${ }^{1}$ Lapin yliopisto, Kasvatustieteiden tiedekunta
}

\begin{abstract}
Mediakasvatuksen kentällä ikäihmisten digitaalisen median taitoja tarkastellaan usein riittämättömyyden näkökulmasta. Myönteisemmälle tulokulmalle on tarvetta, sillä ikääntyneistä jokainen omaa ainutlaatuisen mediasuhteen. Vaikka ikäihmiset ovatkin mediataidoiltaan moninainen ihmisryhmä, heidän yhteiseksi vahvuudekseen voidaan laskea monipuolinen kokemus erilaisten medioiden parista lapsuudesta vanhuuteen. Tutkimuksen tavoitteena onkin selvittää, voisiko kyseisiä mediasuhteiden myönteisiä ominaisuuksia kutsua jopa viisaudeksi. Tutkimus on osa Opetus- ja kulttuuriministeriön Opettajankoulutuksen kehittämisohjelman IkäihMe-hanketta, jota koordinoi Lapin yliopisto. Tutkimuksessa vastattiin kolmeen kysymykseen: 1) Osoittavatko tutkimukseen valitut ikäihmiset viisauden piirteitä mediasuhteissaan ja miten? 2) Miten kokemus näkyy heidän mediasuhteessaan kehittyneissä viisauden piirteissä? 3) Kuinka viisauden tutkiminen sopii mediasuhteiden kontekstiin? Aineisto kerättiin kuudessa yli 65-vuotiaan eläköityneen tietotyöläisen teemahaastattelussa ja analysoitiin teorialähtöisellä sisällönanalyysillä. Haastateltavat osoittivat viisauden piirteitä mediasuhteissaan välittämällä muista sukupolvista digitalisaation pyörteissä, ymmärtämällä yksilöllisiä eroja mediasuhteissa, olemalla kriittisiä mediatarjonnan suhteen ja reflektoimalla omaa mediasuhdettaan. On ilmeistä, että ikäihmisten joukossa on tietoisen sekä kriittisen mediasuhteen omaavia yksilöitä ja se tulisi huomioida tulevaisuuden mediakasvatuksen kentällä.
\end{abstract}

\section{Johdanto}

Mediasuhteet ovat nykyisessä alati digitalisoituvassa maailmassamme keskeinen median oppimiseen ja opettamiseen liittyvän prosessin, mediakasvatuksen, osa-alue (Buckingham 2003; Hakkarainen 2009; Kupiainen 2009). Ikäihmisten median käyttöä koskeva tutkimus on kuitenkin melko yksipuoleista ja keskittyy usein vain digitaalisen median tai tieto- ja viestintäteknologian (TVT) käyttöön ottamisen edessä oleviin esteisiin (ks. esim. Selwyn 2006; Rhoda 2010; Ting 2014; van Deursen, Alexander \& Helper 2015). Vanhempien ihmisten mediasuhteisiin on ylipäätään ollut vähän kiinnostusta viime vuosikymmenten aikana (Kivimäki 2017) sen vähän keskittyessä usein ikääntyneiden ja mediakulutuksen suhteeseen huolen sävyttämänä (Bolin 2013). Esimerkiksi ikäihmisten kykyä tulkita Facebookissa jaettu- 
jen verkkouutisten oikeellisuutta on kuvailtu heikommaksi kuin nuoremman väestön (Guess, Nagler \& Tucker 2019).

Ikäihmisiä olisikin tarpeen tarkastella myös positiivisesta osaamisen näkökulmasta, mikä nostaisi mediasuhteisiin liittyen uudella tavalla esiin niiden ikääntyneiden äänen, joka usein muutoin jää kuulumattomiin. Vaikka ikäihmisten joukko eroaa median ja teknologian käytöltä nuoremmasta väestöstä (Castilla ym. 2018; Taipale \& Hänninen 2018; Tilastokeskus 2018), eivät he ole keskenään homogeeninen ryhmä suhteissaan mediaan (Barrett, Raphael \& Gunderson 2014; Pendergast \& Garattini 2015; Hepp, Berg \& Roitch 2017). Samanikäisiä ei välttämättä voi laskea edes kuuluvaksi samaan mediasukupolveen (Hepp ym. 2017), sillä ikääntyneet poikkeavat mediataidoiltaan ja -tottumuksiltaan toisistaan hyvin paljon (Bergström 2017). Osa omistaa useita älylaitteita ja osalle taas digitaalinen media ei tuo mitään lisäarvoa elämään (Christensen \& Petersen 2017). Monien ikääntyneiden elämässä kuitenkin sekä perinteiset että uudemmat mediat ovat tärkeässä roolissa (Christensen \& Petersen 2017).

Tutkimuksessani tarkoitan ikääntyneillä ja ikäihmisillä 65 vuotta täyttäneitä eläköityneitä henkilöitä (ks. Heikkinen, Jyrkämä, Rantanen 2013; Kivimäki 2017). Mediasuhteita tutkittaessa jaon tekeminen juuri 65 ikävuoden kohdalla on perusteltua, sillä toimintatavat median parissa hajautuvat selvimmin kyseisen ikävuoden tienoilla (Tilastokeskus 2018). Medialla tarkoitan perinteisiä ja digitaalisia joukkoviestimiä, sosiaalista mediaa, teknologiaa sekä median käyttämistä ja tuottamista vuorovaikutuksessa toisten ihmisten kanssa (ks. Seppänen \& Väliverronen 2013; Kivimäki 2017). Ikäryhmän lähestyminen tutkimustarkoituksessa sukupolven näkökulmasta tarkoittaa kuitenkin sitä, että iän lisäksi on keskityttävä mediaan liittyviin kokemuksiin ja tapahtumiin yksilötasolla (Hepp ym. 2017).

Mediasuhteella tarkoitetaan ihmisen kulttuurisesti, yhteiskunnallisesti ja yksilöllisesti rakentunutta suhdetta, jossa korostuu vuorovaikutteisuus eri median käytön tilanteissa, ja joka on muovannut yksilön käsityksiä ja toimintatapoja median parissa ja sitä kohtaan (Hakkarainen 2009; Kotilainen 2009). Mediasuhteissa näkyy vahvasti henkilön elämänkulku, jota ymmärtääkseen on luotava katsaus yksilön historiaan ja sen sosio-kultturisiin rakenteisiin (Elder, Johnson \& Crosnoe 2003; Cooney \& Curl 2019). Iäkkäämpien ihmisten mediasuhteiden yhteisenä etuna voidaan pitää elämän aikana kerättyä monipuolista mediakokemusta. Onhan monen heistä elämänkulku tähän päivään matkannut ainakin paperisten sanomalehtien ja putkitelevision kautta interaktiiviseen tietokoneiden ja älypuhelinten maailmaan. Tässä tutkimuksessa mediasuhteella tarkoitan yksilön itsearvioitua digitaalista osaamista, suhtautumista digitaaliseen mediaan, median käyttöä eri elämänvaiheissa sekä mediavalintoja ja niiden perusteita.

Kokemus ja iän karttuminen tuovat mukanaan hyveitä, joista yhden voidaan mieltää olevan viisaus (Erikson 1959), vaikkakaan ikä sellaisenaan ei ole tutkimusten mukaan yhteydessä viisauden kehittymiseen (Meeks \& Jeste 2009; Sternberg 2013; Ardelt, Pridgen \& Nutter-Pridgen 2019; Glück 2019). Voidaan kuitenkin ajatella, että vaikka ikääntynyt ei automaattisesti ole viisas, on osa heistä saattanut hyödyntää elämänkokemustaan tuottamaan itselleen korkeaa viisautta (ks. Glück 2019). Viisauden osa-alueita ovat myös kokemukseen liitännäinen syvä pohdinta (Ruoppila 2013), reflektio (Csikzentmihalyi \& Rathunde 1990; Bangen, Meeks \& Jeste 2013; Glück \& Bluck 2013), kriittinen ajattelu (Labouvie-Vief 1990), empatia ja toisten eduista välittäminen (Montgomery ym. 2002; Glück \& Bluck 2013; Sternberg 2019a), itsensä ymmärtäminen (Holliday \& Chandler 1986), oman elämän taitava jäsentely sekä itselleen tärkeisiin asioihin keskittyminen (Markkola 2015). Olisiko mahdollista, että pitkä mediahistoria olisi kehittänyt osalle ikäihmisistä jotain näistä ominaisuuksista mediasuhteisiin ja voisiko sitä kutsua jopa viisau- 
deksi? Siihen vastaan tässä artikkelissa kysymyksin: Miten viisaus ja sen osa-alueet voidaan mieltää ja miten ne ilmenevät haastateltavaksi valikoitujen ikääntyneiden mediasuhteissa? Mitä roolia elämänkokemus näyttelee heidän mediasuhteessaan kehittyneessä viisaudessa? Ja viimeisenä: kuinka viisauden tai sen piirteiden tutkiminen onnistuu mediasuhteiden kontekstissa?

Aloitan määrittelemällä, miten itse käsitän viisauden tutkimuskirjallisuuden perusteella. Luon viisauden piirteistä ja ilmentymistä kehikon, jota käytän apuna aineiston tulkitsemisessa deduktiivisesti. Toiseksi, pyrin kategorioita muodostamalla ja nimeämällä kuvaamaan mahdollisimman tarkasti, miten aineistosta löydetyt piirteet ilmenevät. Tarkastelen myös vastaajien elämänkokemuksen roolia viisauden piirteiden esiintymissä. Havainnoin tulosten rinnalla viisauden tutkimuksen sopivuutta mediasuhteiden kontekstissa palauttamalla aineistossa esiintyneet piirteet alkuperäisiin viisauden ilmentymiin ja pohtimalla täten muuttuiko alkuperäisten piirteiden merkitys, kun niitä tarkastellaan mediasuhteen kontekstissa. Pohdintaosiossa vastaan tarkemmin kolmanteen tutkimuskysymykseeni siitä, kuinka viisauden tutkiminen onnistui tutkimukseni kontekstissa suhteessa aiempaan tutkimuskirjallisuuteen.

Tutkimukseni on osa IkäihMe-hanketta (2018-2020), jonka tarkoituksena on pilotoida ja tuottaa Lapin ja Helsingin yliopistojen aikuiskoulutukseen suuntautuville opettajaopiskelijoille ikäihmisten mediakasvatusta koskeva opintokokonaisuus, jota voivat hyödyntää myös aikuiskoulutusorganisaatiot ja vapaan sivistystyön oppilaitokset.

\section{Viisaus ja kokemus sekä elämänkulun merkitys ikäihmisten mediasuhteissa}

Ensimmäisiä viisautta tieteellisenä konseptina käsitelleitä henkilöitä oli psykologi Stanley G. Hall, joka esitteli työssään (1922) viisauden määritelmiä aina Raamatusta asti omaan aikaansa. Jo hänen ajatuksissaan kaikui kokemuksen painottaminen viisauden tutkimuksessa. Hallin $(1922,130)$ mukaan monet järjettömyydet, kuten sodat, olisivat voineet olla vältettävissä, jos vanhuuden ja kokemuksen tuoma viisaus olisi otettu paremmin huomioon poliittisessa päätöksenteossa.

Lähes sata vuotta Hallia myöhemmin Robert J. Sternberg (2019a, 3) toteaa: "Ihmiskunta juoksee väärää kilpailua ja vain viisaus voi saada sen takaisin oikealle radalleen". Erik Erikson (1959) taas esitteli ihmisen psykologisen kehityksen vaiheita, joista viimeisimmässä, vanhuudessa, viisautta pidettiin kyseisen elämänvaiheen hyveenä. Viisaus itsessään on monitahoinen käsite, eikä sen määritteleminen tieteessä ole helppoa (Baltes \& Staudinger 2000), vaikkakin sitä pidetään yhtenä arvokkaimpana ihmisen luonteenpiirteenä (Takkinen, Pakarinen, Aunola, Männikkö, \& Ruoppila 1999, 22; Ruoppila 2013).

1970-luvulta alkaen viisauden tutkimuksessa on esitelty viisi osa-aluetta: maallikkojen käsitykset viisaudesta, viisauden konseptointi ja mittaaminen, viisauden kehittymisen ymmärtäminen, viisauden muovautuvuuden tutkiminen sekä viisauden psykologisen tiedon yhdistäminen elämän eri osa-alueisiin (Staudinger \& Glück 2011). Muinaisen Kreikan käsitysten pohjalle rakentuneen länsimaisen viisauden (Yang \& Intezari 2019) tutkimussuuntauksen mukaan viisautta on pidetty elämän asiantuntijuutena (Baltes \& Smith 1990), luovuuden ja älykkyyden tasapainottamana kokonaisuutena (Sternberg 2019a) sekä itsensä hyväksymisenä asenteiden muuttuessa läpi elämän (Markkola 2015). Viisautta voidaan myös lähestyä henkilökohtaisen tai yleisen viisauden käsitteiden kautta; näistä ensimmäinen viittaa yksilön näkemyksiin omasta itsestään ja jälkimmäinen omien näkemysten soveltamiseen yleisemmässä kontekstissa myös muiden etu mielessä (Staudinger 2013). Yleisesti ottaen jotain tavoiteltavan asian toimintoa ei voida pitää viisaana, ellei se tähtää kohti yhteistä hyvää (Sternberg 2019a). 
Juuri vanhuuden tuomaa viisautta korosti Karl Pillemer (2011), joka keräsi tuhansilta vanhuksilta neuvoja saaden kokoon 30 elämänohjetta. Yhtenä viisauden piirteistä voidaankin pitää juuri neuvojen jakamista ja muiden opastamista (Kramer 1990; Montgomery ym. 2002). Vaikka itse iän vaikutusta viisauden kehittymisessä ei ole voitu todistaa (Sternberg 2013), voidaan ikään liitettävien hyveiden, kuten elämänkokemuksen ja sen hyödyntämisen, katsoa olevan keskeisiä elementtejä viisauden muodostumisessa (Montgomery ym. 2002; Webster 2007; Glück \& Bluck 2013; Sternberg 2013).

Vanhemmat ihmiset omaavat myös taitoja, joissa kyse on elämänkokemukseen pohjautuvasta osaamisesta tai viisaudesta, joilla ylläpidetään ja vahvistetaan hyvinvointia (Fried \& Haarni 2017). Viisaus liitetään usein juuri elämän suurten kysymysten asiantuntevaan käsittelykykyyn, mutta viisaus on myös tilannesidonnaista (Sternberg 1998; Bluck \& Glück 2004). Viisauden tutkimuksessa onkin havaittavissa kaksi suuntausta: viisauden käsitteleminen muuttumattomana persoonallisuuspiirteenä sekä konstruktivistinen tilanteesta toiseen vaihtuva viisaan toiminnan havainnointi, joista jälkimmäinen on suuntauksena yhdenmukainen aristoteelisen käytännöllisen viisauden (phronesis) kanssa (Grossmann, Kung \& Santos 2019). Saattaakin olla mahdollista, että viisautta voisi ilmetä myös ikäihmisten elämänkulun muovaamassa mediasuhteessa.

Elämänkulku on monitasoinen ilmiö, jolla viitataan ikään liittyvien polkujen ja muuttuvien olosuhteiden risteyskohtaan, kuten työuraan ja perhetaustaan (Elder 1994). Elämänkulun näkökulman mukaan yksilöllinen kehitys heijastelee yhteiskunnallisia ja historiallisia muutoksia, joita tietty sukupolvi on kokenut, eikä sitä siksi voida ymmärtää ilman tätä kontekstia (Cohler \& Hostetler 2003). Jokaisen ihmisen mediasuhde on muovaantunut yksilölliseksi elämänkulun aikana tehtyjen mediaan liitty- neiden kokemusten ja valintojen perusteella (Hepp ym. 2017). Iäkkäämmille henkilöille esimerkiksi digitaalisten sovellusten ja laitteiden käyttäminen on helpompaa, jos he voivat kytkeä sen aiempiin kokemuksiinsa (Kuoppamäki 2018). Osa ikääntyneistä saattaa ajatella digitaalisen median olevan jokin kauempana siintävä tavoiteltava "mahdollisuuksien horisontti" (Giskov 2017), osa taas on jo ottanut sen käyttöönsä työelämänsä aikana (Hepp ym. 2017) ja osa ei koe esimerkiksi tietokoneen käyttöä itselleen tärkeäksi (Hakkarainen 2012; Haddon 2018).

Ikäihmiset ovat poikkeuksellisia mediasuhteiltaan, sillä heidän käsityksensä muun muassa siitä, mikä on sopivaa teknologian käyttöä, poikkeaa nuoremmasta väestöstä (Taipale \& Hänninen 2018). On kuitenkin muistettava, että vaikka ihmisiä voidaan jakaa heidän syntymävuotensa perusteella kuuluvaksi samaan "mediasukupolveen", he eivät välttämättä ole lainkaan samankaltaisia mediaan liittyvine tapoineen (Gisgov 2017; Hepp ym. 2017). Mediasukupolven käsite on itsessäänkin jo ongelmallinen, sillä ei voida olettaa, että biologisesti saman ikäiset ihmiset ottaisivat elämänsä aikana samat mediat täysin samoin käyttöönsä (Hepp ym. 2017; Kivimäki 2017). Onkin esitetty, että mediasukupolven käsitettä tulisi uudistaa siten, että se nähtäisiin yhden tai useamman ikäryhmän yhdisteenä, millä on sekä yhteinen kokemus medioista että sukupolvien itsetuntemuksesta (Hepp ym. 2017; Naab \& Schwarzenegger 2017). Monet iäkkäät rakentavat elämänsä kuitenkin itselleen merkityksellisten asioiden ympärille (English \& Carstensen 2014). Ymmärtääkseen mitä media, internet ja digitaaliset taidot merkitsevät yksilölle on heidän elämänkulkunsa otettava huomioon ja arvioitava heidän digitaalista osaamistaan siitä perspektiivistä (Rasi \& Kilpeläinen 2015). 


\section{Aineisto ja menetelmät}

\section{Osallistujat}

Tämän tutkimuksen aineistona olivat kuuden vanhuuseläkkeellä olevan henkilön yksilöhaastattelut. Heistä kolme oli naisia ja kolme miehiä. Yksi haastateltavista oli osa-aikaisesti töissä eläkkeen ohella. Haastateltavista kolme asui pääkaupunkiseudulla ja kolme Rovaniemellä. Iältään he olivat 68-80-vuotiaita, keskiarvolta 72,7 vuotta. Viisi haastateltavista oli käyttänyt tietokonetta työurallaan. Haastateltavat olivat korkeakoulutettuja ja työskennelleet tutkijoina, opettajina, asiantuntijoina ja johtavissa tehtävissä ennen eläkkeelle siirtymistään. Täten heidät voidaan mieltää myös ikääntyneiksi tietotyöläisiksi (ks. esim. Wikisanakirja).

Rekrytoin tutkimukseeni osallistuneet henkilöt IkäihMe-tutkimushankkeen työpajojen osallistujista. Työpajoja oli järjestetty kaksi kappaletta. Valitsin molempien työpajojen osallistujista haastatteluun kolme osallistujaa. Perusteena haastateltavan valintaan oli osallistujan osoittama monipuolinen ja viisautta muistuttava pohdinta työpajan tehtävien tekemisen aikana.

\section{Haastattelut}

Järjestin haastattelut Rovaniemellä ja Helsingissä julkisissa kahviloissa ja tavoittelin niille mahdollisimman rentoa tunnelmaa. Haastattelut kestivät 35 minuutista 80 minuuttiin. Litteroitua tekstiä fonttikoolla 12 ja rivivälillä 1,5 kertyi 7-21 sivua haastattelua kohti, yhteensä 66 sivua. Haastattelurunko sisälsi teemoja, jotka koskivat yksilön mediasuhdetta. Kysymykset liittyivät mediavalintoihin, median ja teknologian käyttöön nyt ja menneisyydessä, suhtautumiseen digitaalista mediaa kohtaan sekä henkilökohtaisiin näkemyksiin median suhteesta yhteiskuntaan menneisyydessä, nyt ja tulevaisuudessa. Lisäksi olin kirjoittanut jokaiselle haastateltavalle 1-4 henkilökohtaista täydentävää kysymystä, jotka liittyivät suoraan työpajassa heidän antamiinsa vastauksiin, joihin kaipasin lisäselvitystä.

Haastatteluita ennen olin toteuttanut esihaastattelun, jossa haastattelin samanaikaisesti kahta ennalta tuttua ikäihmistä. Muokkasin heille tehdyn haastattelun perusteella haastattelurunkoa varsinaisia haastatteluita varten tarkemmaksi, jotta saisin tutkimuskysymyksiin kohdennetummin vastauksia. Tarjosin jokaisessa yksilöhaastattelussa haastateltavalle vapauden puhua omin sanoin ilman rajoitteita, mutta tarpeen vaatiessa ohjasin haastattelua kysymyksin takaisin tutkimukseni teemoihin. Kaikki haastateltavat antoivat luvan haastatteluiden äänittämiselle ja haastattelun sisällön käyttämiseen tutkimusaineistona.

\section{Analysointi}

Analysointia varten oli tarpeellista selvittää, miten viisaus määritellään, jotta sen ilmenemistä voitaisiin tutkia haastateltavien mediasuhteissa. Tulkitsin viisauden ja sen esiintymien määrittelemiseksi tutkimuskirjallisuutta noin 35 vuoden ajalta. Listasin eri tutkijoiden käsityksiä viisaudesta ja sen osa-alueista (liite 1), minkä avulla muodostin 12 eri luokkaa (taulukko 1) viisauden piirteille. Näitä luokkia käytin sisällönanalyysin pohjana deduktiivisesti. Viisauden piirteillä tarkoitan viisaaseen henkilöön liitettäviä ominaisuuksia, viisauteen yhteydessä olevia seikkoja ja viisauden osa-alueita.

Analysoin aineiston teorialähtöisesti ja koodasin haastatteluiden sisällöt analyysiyksiköihin hyödyntäen avointa koodaamista (open coding) (Flick 2002) Atlas.ti -ohjelmalla. Analyysiyksikkönä oli lause tai lauserakenne, jonka tulkitsin sisältävän viisauden piirteitä haastateltavan mediasuhteessa. Hyödynsin viisauden piirteiden luokkia ryhmittelyssä havainnoiden sisältöjen sopivuutta luokkiin. Luokkien tarkoituksena oli myös auttaa analyysi alkuun, ohjata sitä ja saada haastatteluista rajattua merkitykselliset sisällöt. 
Taulukko 1. Tutkimuskirjallisuuden perusteella muodostetut viisauden piirteiden 12 luokkaa.

Älykkyys ja tietämys

Hyvä arvostelukyky, reflektointi ja kriittinen ajattelu

Empatia ja muista välittäminen

\section{Hyvien neuvojen} lähteenä oleminen

\section{Kypsyys ja}

henkilökohtainen kasvu

\section{Itsensä ymmärtäminen} ja omien toimintojen säätely

\section{Tietous, ettei aina tiedä kaikkea ja avoimuus uudelle}

Ymmärrys asioiden tilannesidonnaisuudesta

Monipuolinen ongelmien ratkaiseminen

Kokemus ja sen hyödyntäminen

(Sosiaalinen) mukautuvuus

\section{Eettisyys}

Clayton \& Birren 1980; Csikzentmihalyi \& Rathunde 1990; Arlin 1990; Sternberg 1990, 1998, 2004, 2013, 2019; Ardelt 1997; Montgomery, Barber \& McKee 2002; Meeks \& Jeste 2009; Bangen ym. 2013; Yang 2013; Oakes, Brienza, Elnakouri \& Grossmann 2019

Clayton \& Birren 1980; Holliday \& Chandler 1986; Csikzentmihalyi \& Rathunde 1990; Kitchener \& Brennen 1990; Labouvie-Vief 1990; Sternberg 1990, 1998, 2004, 2013; Ardelt 1997; Webster 2007; Glück \& Bluck 2013; Ruoppila 2013; Oakes ym. 2019

Csikzentmihalyi \& Rathunde 1990; Kramer 1990; Orwoll \& Perlmutter 1990; Sternberg 1990, 1998, 2004, 2013, 2019; Montgomery ym. 2002; Bluck \& Glück 2004; Glück \& Bluck 2013; Ruoppila 2013; Yang 2013;

Grossmann ym. 2019

Holliday \& Chandler 1986; Baltes \& Smith 1990; Kramer 1990;

Takkinen ym. 1999; Montgomery ym. 2002

Arlin 1990; Orwoll \& Perlmutter 1990; Staudinger 2013; Markkola 2015

Holliday \& Chandler 1986; Orwoll \& Perlmutter 1990; Bluck \& Glück 2004i Webster 2007; Glück \& Bluck 2013; Ruoppila 2013; Staudinger 2013; Grossmann ym. 2019

Arlin 1990; Baltes \& Smith 1990; Kitchener \& Brennen 1990; Takkinen ym. 1999; Webster 2007; Glück \& Bluck 2013; Ruoppila 2013; Oakes ym. 2019

Holliday \& Chandler 1986; Baltes \& Smith 1990; Kitchener \& Brennen 1990; Kramer 1990; Sternberg 1998; Takkinen ym. 1999

Clayton \& Birren 1980; Arlin 1990; Kramer 1990; Ardelt 1997;

Bluck \& Glück 2004; Ruoppila 2013; Staudinger 2013; Grosmann ym. 2019

Sternberg 1990, 1998, 2004, 2013; Montgomery ym. 2002; Webster 2007; Glück \& Bluck 2013; Ruoppila 2013; Markkola 2015

Kramer 1990; Sternberg 1990, 1998, 2004, 2013; Bluck \& Glück 2004i Webster 2007; Glück \& Bluck 2013; Ruoppila 2013; Weststrate, Bluck \& Glück 2019

Sternberg 1990, 1998, 2004, 2013; Montgomery ym. 2002; Bluck \& Glück 2004; Ruoppila 2013 
Tämän jälkeen koodasin aineistoa viisauden piirteiden luokkien välillä aksiaalisesti (axial coding) (Flick 2002): etsin yhteyksiä luokkien välillä ja yritin etsiä tarkkaa selitystä tai tarkkoja määritelmiä sille, miten ja missä yhteyksissä viisauden piirteitä esiintyy haastateltavien mediasuhteessa. Nimesin uudet kategoriat, joiden tehtävä oli kuvata tarkasti viisautta muistuttavaa toimintaa haastateltavien mediasuhteessa. Syntyi 15 kategoriaa, joihin sisältyi useita analyysiyksiköitä. Yksittäinen analyysiyksikkö saattoi kuulua useampaan kategoriaan, sillä lausumat eivät olleet aina yksiselitteisiä. Yhteen analyysiyksikköön saattoi myös kuulua useita lausumia, ja yhden lausuman aikana oli mahdollista osoittaa useita viisauden piirteitä.

Tämän jälkeen huomasin, että osa kategorioista tarvitsi uuden määritelmän ja osa ei ollut itsenäisiä kategorioita ollenkaan. Aloitin kolmannen analyysikierroksen: muodostin uudet kategoriat ja annoin niille tarkat määritelmät nimeten myös niiden sisältämät ulottuvuudet. Lopulta syntyi kahdeksan kategoriaa, jotka nimesin kaikki mahdollisimman tarkasti sisältöä kuvaavasti (taulukko 2). Lopulta tarkistin vielä, että kaikki kategoriat ja niiden sisältämät analyysiyksiköt olivat palautettavissa analyysia ohjanneisiin viisauden piirteisiin.

\section{Tulokset}

Ikäihmisten mediasuhdetta koskevien haastatteluiden perusteella syntyi kahdeksan viisauden piirteiden esiintymän kategoriaa: digitaalisten laitteiden ja sovellusten käytön hallitseminen, ennakkoluuloton subtautuminen uuteen tietotekniikkaan, buoli digitalisaation seurauksista, neuvot nuoremmille, mediakokemus ja-bistoria byödynnettynä, notkeus teknisten välineiden käyttämisen ja ilman niitä toimimisen välillä, kriittinen toiminta mediasubteissa sekä monipuolinen ymmärrys mediasubteista.

Jokaisen kategorian esittelyn kohdalla käytän autenttisia lainauksia kuvaamaan sisältöä. Otteiden lopussa on mainittuna haastateltaval- le annettu tunnus (muotoa: $\mathrm{H}$ (numero) ja ikä numeroina, esim. H1, 80), josta selviää haastateltava ja hänen ikänsä.

\section{Digitaalisten laitteiden ja sovellusten} käytön hallitseminen

Haastateltavat kertoivat osaavansa käyttää erilaisia sovelluksia ja digitaalisia laitteita arjessaan. Useasti he myös myönsivät osaamattomuutensa, mutta arkeen liittyvien askareiden hoitaminen digitaalisesti oli heillä kaikilla hallussa. He muun muassa kertoivat osaavansa selata internet-sivuja, käyttää verkkopankkia ja sähköpostia, varata lääkäriajan sähköisesti, lukea digitaalisia sanomalehtiä, käyttää sosiaalista mediaa esimerkiksi sukulaisten elämän seuraamiseen pitkänkin etäisyyden päästä sekä viestiä ja seurata muiden viestejä nuorempien sukupolvien suosimilla viestisovelluksilla.

\section{Se [Whatsapp] on loistava! Ja sitten keskusteluyh-} teys, nämä meidän lapsenlapset kuittailevat toisillensa ja mekin näbdään. [naurua] $(\mathrm{H} 1,80)$

Otteesta voidaan huomata, että vaikka viestien lähettely sovelluksella ei ollut luontevinta, oli sitä mahdollista käyttää muiden vuorovaikutuksen seuraamiseen ja kokea sitä kautta iloa. Digitaalista osaamista voidaan pitää yhtenä viisauden piirteistä, sillä osaaminen on palautettavissa tietämykseen, joka on yksi tutkimuskirjallisuuden perusteella määritellyistä viisauden piirteistä.

\section{Ennakkoluuloton suhtautuminen uuteen} tietotekniikkaan

Haastateltavilla esiintyi ennakkoluulotonta suhtautumista uutta tietotekniikkaa kohtaan eri vaiheissa elämäänsä, mikä on palautettavissa viisauden piirteeseen avoimuus uudelle. Usein, jos haastateltava oli suhtautunut ennakkoluulottomasti uuteen tietotekniikkaan jo aiemmin elämässään, hän otti uuden tietotekniikan ennakkoluulottomasti vastaan myös myöhemmin. 
Taulukko 2. Kategoriat ja niiden ulottuvuudet sekä viisauden piirteet, joihin kategoria on palautettavissa.

\begin{tabular}{|c|c|c|}
\hline $\begin{array}{l}\text { Kategoria sekä } \\
\text { analyysiyksiköiden määrä }\end{array}$ & Ulottuvuudet & $\begin{array}{l}\text { Viisauden piirre, johon } \\
\text { kategorian sisältö on } \\
\text { palautettavissa }\end{array}$ \\
\hline $\begin{array}{l}\text { 1.Digitaalisten } \\
\text { laitteiden ja sovellusten } \\
\text { käytön hallitseminen } \\
\text { (analyysiyksiköitä 25) }\end{array}$ & $\begin{array}{l}\text { Koettu oma osaaminen: älypuhelin, } \\
\text { tietokone, viestintäsovellukset, } \\
\text { sähköiset palvelut }\end{array}$ & Älykkyys ja tietämys \\
\hline $\begin{array}{l}\text { 2. Ennakkoluuloton } \\
\text { suhtautuminen uuteen } \\
\text { tietotekniikkaan (15) }\end{array}$ & $\begin{array}{l}\text { Halukkuus ottaa käyttöön uutta } \\
\text { tietotekniikkaa sekä usko tietotekniikan } \\
\text { elämänlaatua parantavaan } \\
\text { vaikutukseen }\end{array}$ & Avoimuus uudelle \\
\hline $\begin{array}{l}\text { 3. Huoli digitalisaation } \\
\text { seurauksista (63) }\end{array}$ & $\begin{array}{l}\text { Huoli: nuorempien sukupolvien } \\
\text { sosiaalisista suhteista, digitaidoiltaan } \\
\text { heikommista ikäihmisistä, valetiedosta, } \\
\text { tietoturvasta ja -tulvasta, digitaalisen } \\
\text { median riippuvuuksista, tiedon ja } \\
\text { käsittämisen pirstaloitumisesta, } \\
\text { pitkäjänteisyyden katoamisesta }\end{array}$ & $\begin{array}{l}\text { Empatia ja muista } \\
\text { välittäminen }\end{array}$ \\
\hline 4. Neuvot nuoremmille (14) & $\begin{array}{l}\text { Ohjeita koskien sosiaalisia suhteita, } \\
\text { internet-käytöstä ja tiedontulvaa }\end{array}$ & $\begin{array}{l}\text { Empatia ja muista } \\
\text { välittäminen sekä } \\
\text { hyvien neuvojen } \\
\text { lähteenä oleminen }\end{array}$ \\
\hline $\begin{array}{l}\text { 5. Mediakokemus/-historia } \\
\text { hyödynnettynä (49) }\end{array}$ & $\begin{array}{l}\text { Aiemmin opittujen mediataitojen } \\
\text { ja -tapojen myöhempi soveltaminen, } \\
\text { kokemuksen perusteella tehty } \\
\text { päätös jonkin digitaaliseen mediaan } \\
\text { liitännäisen asian rajoittamisesta } \\
\text { tai lopettamisesta, omien } \\
\text { mediasuhteeseen liitännäisten } \\
\text { näkemysten reflektointi suhteessa } \\
\text { kokemukseen }\end{array}$ & $\begin{array}{l}\text { Kokemus ja sen } \\
\text { hyödyntäminen sekä } \\
\text { reflektointi }\end{array}$ \\
\hline $\begin{array}{l}\text { 6. Notkeus teknisten } \\
\text { välineiden käyttämisen ja } \\
\text { ilman niitä toimimisen välillä } \\
\text { (47) }\end{array}$ & $\begin{array}{l}\text { Sovelluksen ja käyttöliittymän } \\
\text { valinta tilanteeseen sopivalla tavalla } \\
\text { digitaalisen ja perinteisen välillä }\end{array}$ & $\begin{array}{l}\text { (Sosiaalinen) } \\
\text { mukautuvuus }\end{array}$ \\
\hline $\begin{array}{l}\text { 7. Kriittinen toiminta } \\
\text { mediasuhteissa }\left(6_{3}\right)\end{array}$ & $\begin{array}{l}\text { Tarkka ja kriittinen henkilökohtainen } \\
\text { viihdevalinta, monipuolinen } \\
\text { yksityisyyden varjeleminen, } \\
\text { monipuolinen, objektiivinen ja tarkka } \\
\text { pohdinta koskien omaa mediasuhdetta, } \\
\text { lähdekriittisyys }\end{array}$ & $\begin{array}{l}\text { Hyvä arvostelukyky, } \\
\text { reflektointi ja kriittinen } \\
\text { ajattelu sekä muista } \\
\text { välittäminen }\end{array}$ \\
\hline $\begin{array}{l}\text { 8. Monipuolinen ymmärrys } \\
\text { mediasuhteista (131) }\end{array}$ & $\begin{array}{l}\text { Useiden eri näkökulmien perusteella } \\
\text { muodostettu ymmärrys omasta } \\
\text { toiminnasta ja omista tarpeista } \\
\text { mediasuhteessaan sekä ymmärrys eri } \\
\text { ihmisten mediasuhteiden yksilöllisistä } \\
\text { ja monitahoisista luonteista }\end{array}$ & $\begin{array}{l}\text { Itsensä ymmärtäminen, } \\
\text { ymmärrys asioiden } \\
\text { tilannesidonnaisuudesta } \\
\text { sekä muista } \\
\text { välittäminen }\end{array}$ \\
\hline
\end{tabular}


Ei ollut ikänä mulla semmosta, että tänne [luokkabuoneeseen] ei tuota [tietokonetta]. Lapsi ois voinu tehdä itsenäisesti [tietokoneella] vaikka kertotauluharjotukset tai joitakin tehtäviä. $(\mathrm{H} 1,80)$

Haastateltava oli työskennellyt luokanopettajana ja ensikohtaaminen tietokoneen kanssa perustui avoimuuteen, sen tervetulleeksi toivottamiseen ja ajatukseen siitä, että siitä saattaisi olla hyötyä myös oppilaille. Sama avoimuus uudelle tietotekniikalle näkyi myös nyt eläkkeellä hänen antamassaan haastattelussa, missä hän kertoi kokevansa nykymedian elämää helpottavana asiana.

Helpottaa ybteydenpitoa nykymedia. Helpottaa tiedonkulkua [...] Mulle on maailma avoin, mä baluan tietää. Se helpottaa sosiaalista kanssakäymistä läheisten kanssa. (H1, 80)

Toinen haastateltava osoitti kiinnostusta tietokonetta kohtaan alun "säikähdyksen" jälkeen ja laajensi tekemistään kiinnostuksen ja ennakkoluulottomuuden avulla myöhemmin erilaisiin tietoteknisiin toimiin.

Kyllä mä siunailin vähän alkuun, mutta kyllä mä sitten kiinnostuin siitä ja värkkäsin vähän sen [tietokoneen] kanssa, että iban turhaankin meni aikaa siiben. $(\mathrm{H} 2,76)$

\section{[...] sitten se alko kiinnostaa enemmän ku tuli nää sähköpostiyhteydet sun muut, vaikka ne oli ensin kaupungin sisäisiä ja sit ne laajeni pikkubiljaa siitä. (H2, 76)}

Ennakkoluulottomuus ei haastateltavien kohdalla tarkoittanut kuitenkaan kaiken uuden tiedon vastaanottamista ilman kriittisyyttä, kuten tulevista kategorioista voidaan huomata.

\section{Huoli digitalisaation seurauksista}

Kategoria huoli digitalisaation seurauksista jakautui useisiin erilaisiin huoliin, jotka koskivat digitaalisen median haittavaikutuksia muille ihmisille ja heidän välisille suhteilleen. Kategorian sisältö voidaan palauttaa viisauden piirteeseen empatia ja muista välittäminen. Vaikka huoli itsessään käsitteenä ei tarkoita suoraan empatiaa tai muista välittämistä, aineistosta nousseissa huolissa korostui vahvasti omasta toiminnasta välittämisen lisäksi myös muiden ihmisten puolesta huolehtiminen ja asioiden havainnoiminen heidän näkökannaltaan. Empatialla tarkoitetaankin "kykyä jakaa muiden tunteita ja kokemuksia kuvitellen olevansa heidän tilanteessaan" (Cambridge, internet-sanakirja) tai "myötätuntoista eläytymistä" (Kielitoimiston sanakirja). Haastateltavat asettautuivat muiden ikäihmisten asemaan digitaalisten palveluiden käyttäjinä tai nuorten sosiaalisten suhteiden ja tiedon rakentumisen tarkkailijoiksi heidän asemastaan käsin.

Huolta osoitettiin ihmisten sosiaalisten suhteiden rapistumisesta, muiden ikäihmisten väliinputoamisesta digitalisoituvassa maailmassa, haitallisen sisällön leviämisestä, digitaalisen median hallitsemattomuudesta, pitkäjänteisyyden katoamisesta ja tiedon käsittämisen pirstaloitumisesta sekä tietoturvasta. Myös huoli tiedon paljouteen liittyvistä uhkista nousi esille.

Digitalisaation ajateltiin olevan omiaan aiheuttamaan epäsosiaalisuutta ja tärkeiksi koettujen kasvokkaisten tapaamisten vähenemistä.

\section{Istuvat kotona ja kattoo jotain ruutua. Vaikka sa-} notaan, että se on sosiaalinen media, niin sebän on epäsosiaalinen. $(\mathrm{H} 6,69)$

Osa haastateltavista esitti huolensa muista ikäihmistä, joilla ei ole eväitä toimia digitaalisessa maailmassa nyt eikä varsinkaan tulevaisuudessa, jos ja kun kaikki palvelut siirtyvät digitaalisiksi.

[...]kun niitä vanbuksia on, joilla ei ole mabdollisuuksia hakea tai tutkia tätä mediavälineistöä, tai että jolla se vastustus on niin kova, että tää ei oo mua varten, mä en halua. Ja se pelko on siinä ehkä se yks. $(\mathrm{H} 1,80)$ 
Haastateltavien keskuudesta nousi esille huoli valeuutisten ja "trollailuiden" leviämisestä ja niiden tunnistamisen vaikeudesta. Tämän katsottiin osittain johtuvan saatavilla olevan tiedon määrästä. Vaikka digitaalisuus koettiin pääosin positiivisesti, koettiin tämä yhdeksi sen negatiivista puolista.

Siis mä luulen, et se mikä täs on se peruskysymys, et miten tästä valtavasta oikean, väärän ja valetiedon tarjonnasta, opittais niinkun löytämään se oikea. $(\mathrm{H} 3,74)$

Tiedon runsaus nousi esille ongelmana, jonka hallitsematon ja jatkuvasti lisää tuottava digitaalinen "mediakoneisto" aiheuttaa. Sen uskottiin ottavan ihmisen valtaansa, jos sille annetaan liikaa valtaa ja unohdetaan muu elämä.

...mut siis tän päivän nuoriso, niin näkee kyllä digitaalisen median nïn keskeisenä juttuna, että niillä ei vaibtoehtoja paljon edes ole, niin mä luulen, et ei ne oikein, et pystyyks ne sitte repimään ittensä pois siitä. Jos se kaikki olis hyvää, niin mikäs siinä. Mutta siin on kyl omat riskinsä. $(\mathrm{H} 6,69)$

Digitaalisen maailman katsottiin olevan riski, joka omii ihmisen itselleen ja siellä olemisen pelättiin olevan ainoa edellytys olemassaololle ja ystävien saamiselle nykymaailmassa.

Ja sit se, et täytyy tehdä kavereita, täytyy tuoda itsensä tykö. Et se mul on pelko siel digitaalises maailmas, et täytyy näkyä kokoajan, et sä oot olemassa, häivyt pois sieltä vähitellen, jos sua ei näbdä siellä, niin sitte sua ei ole siellä. Et se on niinku velvote. $(\mathrm{H} 4,69)$

Suurin huoli kohdistui enimmäkseen nuorempiin sukupolviin ja etenkin niin sanottuihin diginatiiveihin (Prensky 2001). Tiedon katsottiin olevan aina saatavilla, mutta vain yksittäisinä palasina luoden varjopuolen kokonaisuuksien hahmottamiselle.
Pelkään, et se [digitaalinen media] tekee lybytjännitteisemmäks ja pinnallisemmaks. Suurin ubka. Ebkä sellanen isojen kaarien ajatteleminen bankaloituu ja semmonen kärsimättömyys, et jaksatsä istua jonkun, esim. kirjan lukemine on semmosta tyypillistä toubua [...]Mä pelkään sitä, et nuori polvi kärsii koska tulee semmonen tunne, et sun ei tarvi tietää mitään. Et sä aina voit niinkun katsoa. Et mitä biton järkeä on katsoa Westfalenin rauha solmittiin 1648, kun sen voi katsoa sieltä [internetistä]. Mut miten se liittyy niinku kaikkiin niibin tapabtumiin sitä ennen, niin se ei habmotu siinä, jos sä katot vaan jonkun paikan nimen, et se on paljon parempi, jos tietää koko kaaren, et mitkä asiat on johtanu mibinki. (H4, 69)

Vaikka haastateltavat eivät voineet varmaksi esittää haittavaikutusten johtuvan digitaalisesta mediasta, ongelman nähtiin koskevan muitakin kuin vain nuoria. Ajankohtainen käytännön esimerkki tiedon pirstaloitumisesta nousi erään haastateltavan lausahduksessa esille.

No mun mielestä se Trumpin Twitter-tili kertoo jo paljon, se on kolme-neljä riviä siinä ja this is a big statement. Kaikki on niin fragmentoitua. (H6, 69)

Henkilökohtaisten tietojen näkymisestä ja omien asioiden jakamisesta muille internetin kautta oltiin tietoisia ja huolissaan. Huoli koski myös isojen internet-yritysten palveluiden käyttäjien tietojen luovuttamista kolmansille osapuolille.

Mä haluan vetää rajan siihen, varsinki ku on aika paljon ollu tätä, et ne vuotaa kaikennäköstä tietoo ulos. Google esimerkiks ja sitte kaikenlaiset armeijat ja muut käyttää hyväkseen sitten näitä profiileja ibmisistä ja ebkä tulee mainoksia enemmän. Kaikkii tällasii syitä, yritän pysyä erossa. $(\mathrm{H} 4,69)$

Huoli digitalisaation seurauksista -kategoriassa korostui haastateltavien kriittinen pohdinta ja pelko tulevasta. Kyseessä ei kuitenkaan ollut 
paniikin lietsominen tai asioiden näkeminen vain negatiivisessa valossa, sillä kyse oli yksilöistä, joille digitaalinen media ja viestintä olivat antaneet paljon myös myönteisessä muodossa.

\section{Neuvot nuoremmille}

Viisauteen liittyväksi katsottiin neuvojen jakaminen nuoremmille, sillä viisaan henkilön oleminen byvien neuvojen läbteenä oli yksi kirjallisuudesta nousseista piirteistä. Hyvä neuvo on suhteellinen käsite, mutta tässä tapauksessa sellaiseksi laskettiin haastateltavan mediakokemuksen värittämät neuvot, joissa tulkittiin olevan arvokas viesti nuoremmalle sukupolvelle. Neuvoja "diginatiiveille" pyydettiin haastateltavilta suoraan, mutta niitä tuli myös muun puheen joukossa. Neuvot liittyivät sosiaalisten suhteiden vaalimiseen, hyvään internet-käyttäytymiseen, mediakriittisyyteen ja etenkin digitaalisen median käsittelemiseen vain yhtenä osana elämää.

Eläkää elämää. Eläkää elävää elämää. Se on kone... Se on vähän kun vanha sanonta, tuli on byvä palvelija, mutta huono isäntä. (H1, 80)

Vinkkejä jaettiin myös tiedon rakentamiseen useista kanavista samaan aikaan, ettei se jäisi irralliseksi.

Olis hyvä käyttää jotain Wikipediaa ja katsoo väbän taustoja mielellään jo ennen ku katsoo [dokumentteja], et on joku käsitys siitä mitä oikeesti tapabtu. $(\mathrm{H} 4,69)$

\section{Mediakokemus/-historia hyödynnettynä}

Mediakokemus/-historia hyödynnettynä -kategoriaan laskettiin haastateltavien lausahduksia, joissa aiemmin elämässä opittua mediaan tai teknologiaan liittyvää taitoa sovellettiin tai jatkettiin eri tavoin myöhemmin elämässä. Myös jonkun opitun liiallisuuksiin menneen digitaalisen tavan rajoittaminen, erheestä op- piminen ja kokemuksen perusteella muodostetut näkemykset katsottiin viisauden piirteitä ilmentäviksi seikoiksi. Kategorian sisällöt ovat palautettavissa viisauden piirteistä kokemuksen byödyntämiseen ja kriittiseen ajatteluun ja reflektointiin.

Yksi haastateltavista kertoi, että suosii läheisilleen viestimisessä mieluummin sähköpostia kuin tekstiviestiä. Kirjeiden kirjoittamista ja lähettämistä hän oli harrastanut jo opiskeluvuosinaan. Nyt hän sovelsi tuota tapaa ja taitoa sähköpostiviestien lähettämisen tukena.

Mä haluan kirjottaa vähän enemmän kuulumisia ja tapahtumia ja tuntemuksia. Tai siis niinkun yleensäkin kuin kirjoittaisin kirjettä. (H1, 80)

Toisen haastateltavan työskenteleminen paikallislehden kesätoimittajana nuoruudessaan auttaa häntä yhä kiinnittämään huomiota enemmän eri yhtiöiden tapaan tuottaa uutisia.

Kyllä mä varmaan vieläkin kiinnitän huomiota siiben, miten ne asiat muotoillaan ja otsikointia ja läbinnä vertailen aina sitä MTV:n ja Ylen tapaa tebdä untisia. $(\mathrm{H} 3,74)$

Osa haastateltavista kertoi, että lapsuuden kotiin oli tullut sanomalehtiä ja niitä oli luettu jo lapsena. Haastateltavat yhdistivät puheessaan tämän kokemuksen nykyiseen säännölliseen tapaansa lukea sanomalehtiä arjessaan.

[...] ihan pienestä lapsesta muistan, että luin sarjakuvat lehdestä.... meille tuli Åbo Underrättelser ja Huvudstadsbladet. Luin niistä kymmenen vuotiaaksi asti pelkät sarjakuvat. Ja jotain urbeilu ja ehkä jotain tämmöstä. Kyllä mä tänäkin päivänä, Hesari ja Huvudstadsbladet, luen joka aamu siinä aamiaisen ybteydessä. Vaimo lukee tavallisesti ensin Huussiksen ja mä luen Hesarin ja sitten vaihetaan ja keskustellaan samalla niistä. $(\mathrm{H6}, 69)$

Haastateltavat olivat olleet mukana sosiaalisessa mediassa tai jossain muussa digitaalista taitoa vaativassa asiassa, mutta osa heistä kuiten- 
kin havainnut sen haitallisuuden tai tarpeettomuuden itselleen ja rajoittanut tai lopettanut kyseisen toiminnan kokonaan. Eräs haastateltavista kertoi, että huomattuaan olevansa lievästi riippuvainen tietokoneesta, hän nykyään puuttui asiaan: Kyllä mä yritän pitää pitempiä välejä ennen ku menee koneelle. $(\mathrm{H} 2,76)$

Yksi haastateltavista kertoi käyttävänsä Facebookia ystäviensä, perheensä ja tuttaviensa kuulumisten seuraamiseen, mutta omien päivitysten kirjoittamisen ja jakamisen hän oli kokenut melko turhaksi ja vähentänyt siksi sen käyttöä.

Nii mä hah, viime kesänä se oli viime kerta ku mä jotain pistin. Tää tybmä Facebook kysyy mitä mä tässä teen, no mä juon ybden oluen ja oon rannalla saaristossa ja nautin auringosta, tää on tää mitä teen. Tuli paljon positivista ja oli kiva juttu, mut ei siis sillä oo mitää järjellistä merkitystä. (H6, 69)

Kokemuksen perusteella muodostettuja näkemyksiä oli kuultavissa paljon haastateltavien puheessa. Niihin luokiteltiin lausahdukset, joista oli huomattavissa koettujen yksilöllisten ja yhteiskunnallisten asioiden vaikutus haastateltavan mielipiteen muodostamiseen mediasuhteessaan. Lausahduksissa oli nähtävissä reflektointia menneen ja nykyisen välillä.

\section{Kyllä sitä on monta kertaa ibmetellyt, että miten} sitä pysty toimimaan tai elämään ilman pubelinta. Nykysin ainakin on mahdollisuus tietää missä lapset on. Mä muistan kun mä joskus myöbästyin viimesestä bussista, niin ei ollut mahollisuutta soittaa. (H5, 68)

"Kantapään kautta" koettuja ikäviä asioita osattiin myös hyödyntää. Eräs haastateltavista kertoi joutuneensa huijauksen kohteeksi internetissä sijoitettuaan rahaa kryptovaluuttaan. Tapahtuman jälkeen hän oli muuttunut varovaisemmaksi ja tulkitsee siksi uutisia ja ilmoituksia kriittisemmin kuin ennen. Toinen haastateltava oli kirjoittanut omasta mieles- tään liikaa sähköpostiviestejä vähäpätöisistäkin asioista ja hieman malttamattomasti purkanut tuntojaan työelämässään viestien lähettämisen helppouden takia. Hän kertoi, että kokemus oli kuitenkin pakottanut hänet maltillisemmaksi viestien lähettämisessä.

Notkeus teknisten välineiden käyttämisen ja ilman niitä toimimisen välillä

Notkeudella tässä yhteydessä tarkoitettiin haastateltavien kykyä toimia digitaalisessa maailmassa digitaalisin välinein ja sovelluksin, mutta myös ilman niitä tarpeen vaatiessa. Kyseessä oli viisauden piirre haastateltavien (sosiaalisesta) mukautuouudesta erilaisiin tilanteisiin omien tai muiden tarpeiden vaatimalla tavalla.

Osa haastateltavista luki yhä vanhoille tavoilleen uskollisena paperista sanomalehteä, mutta osasi ja halusi kuitenkin lukea myös digitaalisia verkkolehtiä ajoittain.

Iltalehdet mä luen netistä. Ja mitä on näitä otsikoita ja muita, ne tulee ladattua moneenkin kertaan, koska silloinhan on helppo nähdä, että mitä tapahtuu.... mutta silti siellä [paperisessa lehdessä] on paljon semmosia juttuja, artikkeleita, jotka syventävät sitä asiaa, että se on helpompi lukea ne isot jutut sieltä lebdestä. $(\mathrm{H} 2,76)$

Oli myös huomattavaa, että tekniset välineet olivat tulleet avuksi erilaisissa toiminnoissa, mutta ne eivät olleet syrjäyttäneet kokonaan vanhoja itselle hyviksi koettuja tapoja. Monet haastateltavat myönsivät yhä käyttävänsä kynää ja paperia muistiinpanojen tekemiseen, vaikka käyttivätkin tietokonetta pidempien tekstien kirjoittamiseen.

Haastateltavat korostivat sosiaalisten suhteiden ylläpitämistä kasvokkain, mutta olivat myös ottaneet käyttöön erilaisia teknisiä sovelluksia ja välineitä yhteydenpitoon.

No onhan se ihan hyvä, että sosiaalinen media on olemassa, kun aika monet ihmiset on aika kaukana...on kiva saada valokuvia lapsenlapsista ja 
kaikkea semmosta mitä voi nopeesti lähettää ja pysyy ajantasalla, mutta siinä on byvät ja huonot puolensa. En mä sillä lailla olis sitä mitenkään poistamassa, tai että pitäis aina puhua kasvokkain, mutta on hyvä pubua aina välillä kasvokkain. (H5, 68)

Tässäkin kategoriassa korostui itselle parhaalta tuntuvan tavan omaksuminen tilanteesta riippuen, mutta myös vastaanottajan tarpeet otettiin huomioon epäitsekkäästi.

Kyl mä vielä tyttären kanssa pubun pitkät soitot. Poikien kanssa tulee sit enemmän laitettua kuvia ja viestejä. Toista poikaa mä näänkin usein kun bän asuu tässä. (H5, 68)

\section{Kriittinen toiminta mediasuhteissa}

Kriittiseksi toiminnaksi tulkittiin tarkkuus mediavalinnoissa, yksityisyydestä huolen pitäminen, pohdinnassa ilmennyt monipuolisuus ja lähdekriittisyys. Kriittinen toiminta tässä kategoriassa on palautettavissa viisauden piirteisiin byvä arvostelukyky, reflektointi ja kriittinen ajattelu sekä itsensä ymmärtäminen.

Kaikkien haastateltavien mediasuhteessa korostui käytettävän, katsottavan tai kulutettavan median valitseminen tarkkaan harkiten.

Ebkä jos joku on referoinu niitä [TV-tarjontaa], niin saatan merkata sieltä [lebdestä], tai sit jos sattuu silmään. En mä orjallisesti noudata niitä, mut illalla mä avaan sen ja katson sieltä mitä mä oon rengastanu ja päätän, et haluaks mä katsoa tollasta tänään. Saattaa mennä yli, tai sit mä saatan tallentaa sen, jos on jotain muuta tekemistä. $(\mathrm{H} 4,69)$

Mediatarjonnan radiossa, aikakauslehdissä tai televisiossa haluttiin olevan jollain tavalla kiinnostavaa, asiapitoista tai itseä kehittävää. Jos ohjelma ei sen katsomisen aikana miellyttänyt, se suljettiin nopeasti. [...]ebkä lukee lebdestä, et nyt taas alkaa joku uus sarja, ja no katotaan annetaan sille mabdollisuus ja sit ku mä oon kattonu puol tuntii, niin "ei tää oo meidän juttu”. (H6, 69)

Lähes kaikki haastateltavista olivat vähintään jossain vaiheessa elämäänsä liittyneet Facebookiin ja käyttäneet sitä. Ainoa haastateltava, joka ei ollut sinne koskaan luonut itselleen tunnusta, harkitsi liittymistä kyseiselle sivustolle, mutta vain siten, että hänestä näkyisi siellä vain pieni osa henkilökohtaisista tiedoista ja jopa ilman profiilikuvaa. Tämä kieli oman yksityisyyden varjelemisesta. Toinen haastateltava mainitsi noudattavansa sosiaalisessa mediassa varovaisuutta oman sijaintinsa ilmoittamisessa tiedostaen, että väärissä käsissä oman asunnon tyhjillään olemisen tieto voi koitua kohtalokkaaksi: Noo, ainakaan mä en ilmoittele et missä mä oon milloinkin, koska täl hetkellä asun yksin. (H5, 68)

Oman julkisen ja yksityisen minän välille tehtävää eroa pidettiin myös tärkeänä.

Noo kyllä kai mä sanon sillon ku on sanottavaa ja muotoilen sen sit kunnolla, mutta en mä mene joka paikkaan peukuttamaan [...] en kommentoi julkisesti, mä haluan pitää etäisyyttä siiben julkisuuteen, julkiseen puoleen ja omaan itseeni. (H2, 76)

Monipuolinen ja tarkka pohdinta ilmeni pitkin haastatteluita ikään kuin metatasolla keskustelussa. Haastateltavat pohtivat myös digitaalisen median ja yksilön välistä suhdetta, ja heidän ajatuksissaan nousi esille lähdekriittisyys uutisten suhteen ja tiedon oikeellisuuden tunnistaminen eri keinoin. Ihmisten tietämysten välisiä eroja ja sen yhteyttä tiedon ja valetiedon erottamiseen pohdittiin myös.

Kun mennään semmoselle alueelle, josta itellä ei oo ees perustietoja, niin siinä voi helposti tulla tämmösen valetiedon, tai väärän tiedon läbteelle[...] pubuisko jostain rajatiedosta, tai tämmösessä jossa vaaditaan jo korkeaa perustietoa. $(\mathrm{H} 3,74)$ 
Monipuolinen ymmärrys mediasuhteista

Monipuolinen ymmärrys mediasuhteista -kategoria muodostui haastateltavien osoittamasta itsensä, eri yksilöiden ja ikäpolvien sekä yhteiskunnan välisistä ja sisäisistä eroista koskien monimutkaisia mediasuhteita. Kategorian sisällään pitämien lausahdusten myötä tuli esille viisauden piirteistä itsensä ymmärtäminen, muista välittäminen, ymmärrys asioiden tilannesidonnaisuudesta ja kokemuksen byödyntäminen. Itsensä ymmärtämistä katsoin tapahtuvan, jos haastateltava ei pelkästään todennut toimivansa jollain tavalla mediasuhteessaan, mutta myös kertoi syyn toiminnalleen. Yksi haastateltavista ymmärsi, miksi opiskeluaikoina yhteydenpito kotiin oli ollut vähäistä.

En todellakaan [kaivannut enempää yhteydenpitoa perbeeseen], et sen takia, että [opettajankoulutus-]seminaari, joka oli kansakouluopettajien seminaari oli [kaupungin] kulttuurisydän. Siis siellä oli niin paljon tapabtumaa, ybteisö, ja neljä vuotta se aika. Siellä oli kuoro, siellä oli liikunnalliset harrastukset opiskelun lisäksi. (H1, 80)

Oli myös kiinnitetty huomiota oman kriittisyyden vaihteluun mediasuhteessaan.

Joskus olen byvin kriittinen ja joskus buomaan, että oon kaikkea muuta kuin kriittinen, että menee ihan höpöhöpö-hommaksikin. $(\mathrm{H} 2,76)$

Vastauksista oli nähtävissä perusteluja, miksi sosiaalinen media ei enää tuntunut itselleen järkevältä. Henkilökohtainen kokemus auttoi jäsentelemään suhdettaan siihen.

Tänä päivänä se on kyl enemmän negatiivinen. Mul on Facebook-tili, mul on toi Linkedin-tili, mul on jotain muita. Facebookis mä en ole koskaan, olen mä ehkä joskus vuos sitten pannu jotain sinne itse. Mut kyl mä luen sielt juttuja, tuttujen juttuja. Mut sit siel on niin paljon, ihan vaan mainoksia ja krääsää, joka on vaan häiritsevää. Mä aattelin, et mä oisin iloisempi jos mulla ei olis sitä. (H6, 69)
Haastateltavat ymmärsivät, että nuoremmilla on erilainen suhde sosiaaliseen mediaan kuin heillä itsellään.

Kyl se [kummityttö] pärjäis niinku minäkin, mut kyl se vähän on, kun ne kaverit on siellä. Mun kaverit ei oo Facebookissa. Ja niistä kavereista, jotka mä tiedän, et on siellä, niin ei ne hirveesti postaile siellä. Enemmänki semmonen tiedotuskanava tai semmonen... et kyl ne sen ikäset ja siitä nuoremmat. Must tuntuu, et se koettais hyvin omituiseks, jos ne ei olis siellä... Mun ikäsillä ei taas tuu sellasta, et sä oot outo. Et olis ebkä kiva, jos sä olisit siellä, mut ei kukaan ajattele, et sä oot outo. (H4, 69)

Esille nousi myös se, ettei ketään, etenkään ikäihmisiä, voi pakottaa siirtymään digitaaliseen maailmaan ilman tarvittavia resursseja. Osa haastateltavista huomioi myös sen, että sukupolvierojen lisäksi jokaisella ihmisellä on yksilöllisesti rakentunut suhteensa mediaan.

Se on vähän kysymys siitä, että mitä ite subtautuu tämmöseen informaatiotavaraan. Mitä haluaa käyttää siitä, että haluaako kattoo videoita, tai mennä tämmöselle viihdepuolelle, että mikä on se oman mielenkiinnon ja halun kohde. Että se on vähän tämmönen persoonakohtainen. $(\mathrm{H} 2,76)$

Monipuolista ymmärrystä osoittavat haastateltavat ikäihmiset korostivat henkilökohtaista viisautta ottamalla huomioon omat tarpeensa ja ymmärtämällä omien toimintatapojensa syitä. Yleistä viisauttakin (ks. mm. Staudinger 2013) tässä kategoriassa oli havaittavissa, sillä ajatuksissa olivat myös muut ihmiset ja heidän yksilölliset tarpeensa.

\section{Tulosten yhteenveto}

Tutkimuskirjallisuuden perusteella muodostettujen kahdentoista viisauden piirteen luokan mukaan kohderyhmän ikäihmiset osoittivat mediasuhteissaan yhdeksän luokan sisällään pitämiä viisauden piirteitä erilaisissa tilanteissa. 
Viisauden piirteistä älykkyys ja tietämys, reflektointi ja kriittinen ajattelu, empatia ja muista välittäminen, byvien neuvojen läbteenä oleminen, itsensä ymmärtäminen, avoimuus uudelle tiedolle, ymmärrys asioiden tilannesidonnaisuudesta, kokemus ja sen byödyntäminen sekä sosiaalinen mukautuvuus olivat edustettuina haastateltavien mediasuhteissa. Viisauden piirteet ilmenivät mediasuhteissa digitaalisten laitteiden ja sovellusten käytön hallitsemisena, ennakkoluulottomana suhtautumisena uuteen tietotekniikkaan, huolena digitalisaation seurauksista, neuvoina nuoremmille, notkeutena teknisten välineiden käyttämisessä, kokemuksen hyödyntämisenä mediasuhteissa, kriittisenä toimintana mediasuhteissa sekä monipuolisena ymmärryksenä mediasuhteista.

Elämänkulun aikana karttuneella kokemuksella oli roolinsa haastateltavien mediasuhteissa esiintyvissä viisauden piirteissä. Haastateltavat kertoivat soveltavansa aiemmin jo ennen digitaalista aikakautta oppimiaan mediataitoja digitaalisilla alustoilla. Esimerkiksi kirjeiden kirjoittamisen koettiin helpottaneen sähköpostin käyttöönottoa, sillä toiminnot muistuttivat toisiaan. Kokemus oli myös opettanut osalle heistä varovaisuutta nettihuijausten kanssa tai rajoittamaan tietokoneen tai internetin käyttöä siihen kehittyneen riippuvuuden takia. Osa heistä oli myös ehtinyt todeta sosiaalisen median itselleen tarpeettomaksi vähentäen tai lopettaen sen käytön. Pitkin haastatteluja oli huomattavissa, että haastateltavat peilasivat nykyistä mediasuhdettaan entiseen. He vertailivat sitä, kuinka paljon jotain tiettyä mediaa ennen kaivattiin henkilökohtaisella tai yleisellä tasolla, miten se on saattanut muuttaa omaa elämää ja mikä merkitys medialla on tänä päivänä eri ihmisille. Kokemus kulminoitui heidän näkemykseensä mediasta ajalta ennen digitaalisuutta ja sen jälkeen.

\section{Pohdinta}

Tutkimukseni tarkoituksena on lisätä ymmärrystä ikäihmisten mediasuhteista ja niissä esiintyvistä ominaisuuksista sekä osoittaa, että vaikka tutkimuskirjallisuudessa usein viitataan vanhemman väestön heikompiin taitoihin digitaalisen median parissa, eivät kaikki vanhemman väestön edustajat kuulu kyseiseen joukkoon, ja ikäihmisissä on myös mediasuhteeltaan taitavia, kriittisiä, itsetietoisia ja viisauden piirteitä osoittavia henkilöitä. Avatakseni oven viisauden tutkimukselle ikäihmisten mediasuhteissa haastattelin kuutta henkilöä, jotka olivat lähtökohtaisesti osoittaneet viisauden piirteitä pohdinnassaan IkäihMe-hankkeen työpajoissa keväällä 2019. He olivat kaikki korkeakoulutettuja ja työskennelleet työurallaan asiantuntijoina, opettajina, johtajina tai tutkijoina. Heistä lähes kaikilla oli kokemusta tietokoneen käyttämisestä työurallaan. Heitä voitaisiin siis kuvailla ikääntyneiksi tietotyöläisiksi ja siten he olivat ikäihmisiä edustavana joukkona hyvin omaleimainen.

Haastateltavat olivat keskenään eri-ikäisiä. Vanhin heistä oli syntynyt 1930-luvun lopulla ja nuorin 1950-luvulla. He olivat ottaneet käyttöönsä erilaisia medioita eri vaiheissa elämäänsä muovaten siten mediasuhteensa omanlaisikseen. Tällöin heidän niputtamisensa mediasuhteiltaan samanlaisiksi ei olisi oikeutettua. Osalle esimerkiksi tietokoneen käyttäminen oli luontevampaa kuin toisille. Kuitenkin heille yhtäläistä oli se, että jokainen oli kohdannut digitaalisuuden jo työelämässään. Tästä näkökulmasta katsottuna haastateltavat voisi mieltää kuuluvan massamediasukupolven sijasta "voileipäsukupolveen", joka kasvoi perinteisten medioiden kuten radion, sanomalehtien, kirjepostin ja lankapuhelimen aikakaudella, mutta joka omaksui digitaaliset mediakäytänteet työelämässään ja otti ne osaksi omaa "mediarepertuaariaan" (ks. Hepp ym. 2017). 
Haastateltavien osoittamien viisauden piirteiden monet merkitykset

Haastateltavat osoittivat viisauden piirteitä kertomalla olevansa osaavia ja tietoisia digitaalisen median ja laitteiden kanssa. Oli selvää, että he osasivat käyttää niitä omiin tarpeisiinsa ja viestintään läheisten ja tuttavien kanssa monin eri sovelluksin (ks. myös Sims, Reed \& Carr 2017; Tilastokeskus 2018). Silmiinpistävää teknologian käyttämisessä oli kuitenkin se, että sosiaalista mediaa käytettiin rajatusti, minkä perusteella haastateltavista voisi käyttää termiä narrow users (ks. esim. Ofcom 2019). En kuitenkaan kokenut kapeahkoa sosiaalisen median käyttämistä negatiiviseksi aspektiksi, vaan haastatellut räätälöivät sosiaalisen median tarkkaan omiin tarpeisiinsa. Osa haastateltavista oli käyttänyt esimerkiksi Facebookia, mutta poistunut sieltä (ks. myös Hepp ym. 2017), sillä sitä ei koettu tarpeelliseksi. Whatsappia käytettiin perheen jutustelun seuraamiseen, mutta siellä ei osallistuttu kovinkaan paljon viestejä tuottamalla, vaikka osaamistakin siihen olisi löytynyt. Tutkimuksissa otetaan harvoin huomioon, että ikäihmisten väestön joukossa on olemassa osa, joka osaa käyttää laitteita ja sovelluksia yhtä hyvin kuin muutkin mutta vain valikoidusti.

Haastateltavat osoittivat viisauden piirteitä pohtiessaan digitaalista mediaa myös sen haittavaikutusten kannalta yksilöille ja yhteisöille. Vaikkakin he olivat suhtautuneet uusiin teknologioihin ennakkoluulottomasti elämänsä aikana, ei digitaalista tekniikkaa ja mediaa otettu vastaan ilman kritiikkiä (ks. myös Giskov 2017). Tämä on tärkeää tiedostaa pohdittaessa ikäihmisten digiopastusta ja mediakasvatusta, sillä opastuksen tai kasvatuksen vastaanottajalla saattaa olla hyvä tieto-taito uuden median haltuun ottamiseksi, mutta kriittinen suhtautuminen jarruttaa hieman omaa toimintaa. Haastateltavista osa kertoi myös kokevansa olevan vähemmistönä digitaalisen median käytön hallitsevassa ikäihmisten joukossa. He olivat huolissaan niistä ikäihmisistä, joilla ei ole välineistöä tai osaamista palveluiden äärelle pääsemi- seen, mikä pahimmillaan voi johtaa ikääntyneiden syrjäytymiseen yhteiskunnasta (Friemel 2016).

Haastateltavat ymmärsivät mediasuhteiden yksilölliset erot tiedostaen, että nuoremmilla sukupolvilla sosiaalisen median jatkuva läsnäolo on lähes välttämättömyys vertaissuhteiden ylläpitämisessä eivätkä siksi nuoria siitä tuominnetkaan (ks. myös Murumaa-Mengel \& Siibak 2019, 270). He kuitenkin varoittelivat digitalisaation vaaroista sosiaalisille suhteille tai yksilön tiedon rakentumisen kehittymiselle ja neuvoivat käyttämään sitä vain tarpeisiin, niin että se olisi käyttäjän renkinä, ei isäntänä (ks. myös Hakkarainen 2012; Gisgov 2017). Tähän liittyvät neuvot lienevät paikallaan, sillä esimerkiksi sosiaalisen median käyttäminen, yhdistettynä ulkopuolelle jäämisen pelkoon, on todettu aiheuttavan riippuvuutta sosiaalista mediaa kohtaan (Blackwell, Leaman, Tramposch, Osborne \& Liss 2017). On myös huomattu, että suomalaisten luontoharrastaminen on vähentynyt, minkä yhdeksi syyksi arvioidaan juuri sosiaalisen median virtuaalisten yhteisöjen laajaa tarjontaa (Tilastokeskus 2017). Ei olekaan ihan täysin selvää, onko media ja teknologia ihmisten ajatuksia ja käytöstä ohjaavia välineitä vai niiden käyttäjää voimaannuttavia työkaluja (Fortunati 2014).

Voidaan ajatella, että digitaalinen kuilu, jonka on nähty olevan lähinnä ikäihmisten ja nuoremman väestön välillä, on osittain siirtynyt myös ikääntyneen väestön sisälle. Osa mediaan liittyvistä ikäkuiluista näyttääkin parhaillaan sulkeutuvan, esimerkiksi internet ja Facebook ovat enenevissä määrin myös vanhempien sukupolvien käytössä (Bolin 2013). Tutkimukseni tulokset todistivat, että mediasuhteessaan taitavien ikäihmisten joukko on kirjava: he pitävät hallussaan samoja mutta myös toisistaan poikkeavia taitoja. Tulevaisuudessa ikäihmisten joukossa tullee olemaan entistä enemmän täysin digitaalisesti taitavia ihmisiä, mutta kuilu heidän ja osaamattomien vanhemman väestön edustajien välillä saattaa vielä syventyä. Aiempien tutkimusten mukaan esimerkiksi opiske- 
lutausta ja työskentely niin kutsutuissa valkokaulustöissä on yhteydessä myöhempään tietokoneen käyttötaitoon, internetin käyttöön ja minäpystyvyyteen (Kämpfen \& Maurer 2018; Bergström 2017). Tämä on tärkeää tiedostaa kohdatessa ikäihmisiä heidän tarpeidensa pohjalta mediakasvatuksen kentällä.

Kokemusta on pidetty yhtenä keskeisenä viisauden rakentajana (esim. Sternberg 2013). Tämä oli myös nähtävissä tämän tutkimuksen tuloksista, joissa haastateltavien kokemuksen tuoma näkemyksellisyys korostui heidän mediasuhteissaan. He olivat oppineet virheistään, hyödyntäneet osaamistaan perinteisten mediamuotojen ja uusien välillä itselleen sopivilla tavoilla, mutta mikä tärkeintä, he tiesivät mitä on elää ilman jatkuvaa mediatulvaa. He korostivat sosiaalisten suhteiden ylläpitämistä kasvotusten, vaikkakin sosiaalisen median käyttäminen luonnistui ja he ymmärsivät, ettei digitaalinen media voi olla ihmiselle kaikki kaikessa. Vanhoja hyviksi koettuja tapoja ei heitetty uuden edellä roskakoriin vaan niitä sovellettiin rinnakkain, jotta omat ja läheisten mediaan ja yhteydenpitoon liittyvät tarpeet tulisivat tyydytetyiksi.

Vaikka aineistosta nousi esille kohtia, joissa nykyinen digitaalisuus nähtiin myös kielteisenä asiana, eivät haastateltavat profiloituneet, eivätkä he profiloineet itseään, "dinosauruksiksi", jotka kieltäytyisivät kokonaan käyttämästä internetiä (vrt. Rasi \& O’Neal 2014). He yksinkertaisesti hyödynsivät kokemustaan viisaasti katsomalla molemmin puolin "digikuilua" ja valitsemalla itselleen parhaimman tavan toimia. Tämä onkin mielestäni tutkimukseni tärkeintä antia kokemuksen tuomien viisauden piirteiden osalta. Korkean iän ei ole todistettu olevan yhteydessä viisauteen (Meeks \& Jeste 2009; Sternberg 2013; Ardelt ym. 2019; Glück 2019) ja joissakin tutkimuksissa sen on jopa todettu olevan todella iäkkäillä alemmalla tasolla kuin nuoremmilla ihmisillä (Glück 2019). Kokemuksen ei itsessään myöskään ole todistettu synnyttävän kenellekään viisautta, mutta pitkän kokemuksen tai kriittisten elämänko- kemusten avulla yksilön on kuitenkin ajan kuluessa mahdollista muodostaa itselle viisautta (Glück 2019). Onkin oleellista ottaa huomioon, että ihminen on saattanut tulla viisaammaksi iän myötä omaan lähtötasoonsa nähden, vaikkakaan hän ei olisi yleisellä tasolla luettavissa viisaaksi (ks. Glück 2019). Saattaakin olla mahdollista, että tutkimukseni haastateltavat olivat mediasuhteissaan viisaampia kuin he olivat siinä suhteessa nuoremmalla iällään.

Haastateltavat olivat erittäin tarkkoja siitä, mitä he medialta haluavat itselleen ja siten oman parhaansa ajattelu voidaan nähdä henkilökohtaisena viisautena (ks. mm. Staudinger 2013). Jos viihdeohjelmista ei pidetty, laitettiin televisio kiinni. Tärkeintä oli kuitenkin, että haastateltavat olivat kriittisiä uutisten suhteen. He tiedostivat huijatuksi tulemisen uhat ja ymmärsivät, että on tarpeellista vertailla uutisia ja sitä, millaisten lähteiden perusteella ne oli tehty. Ikäihmisten joukossa on todettu olevan enemmän kyvyttömyyttä tunnistaa esimerkiksi Facebookissa jaettuja valeuutisia (Guess ym. 2018), mutta tässä tutkimuksessa tämä ei näyttäytynyt ongelmana, vaikkakin valeuutisten tunnistamisen tiedettiin olevan haasteellista.

Tutkimuksen rajoitteet ja jatkotutkimustarpeet: viisautta vai viisauden piirteitä?

Viisauden piirteiden arvioiminen liitetään usein syviin elämään liittyviin asioihin, jolloin viisauden ilmenemisen ja sen arvioimisen tulee olla perusteellista. Vaikka mediakasvatus ja mediasuhde ovatkin tärkeitä asioita, ne ovat vain yksi osa elämää ja siksi pinnallisempi kokonaisuus kuin elämä itsessään. Tästä johtuen myös viisauden ilmeneminen ja sen arvioiminen mediasuhteissa tapahtuu luonnollisesti pinnallisemmalla tasolla kuin elämän viisauden arvioiminen. Lähestyin viisautta täten kontekstiin sidonnaisella tavalla, jolloin tutkimani viisauden piirteet eivät olleet viisautta ainakaan niin sanotun trait-suuntauksen (Grossmann ym. 2019) mukaan, jossa viisaus mielletään vakaak- 
si ja muuttumattomaksi luonteenpiirteeksi tilanteesta riippumatta. Tilanteesta toiseen vaihtelevana state-viisautena (Grossmann ym. 2019) löytämäni piirteet voisivat helpommin olla käsitettävissä.

Iän ja viisauden yhteys riippuukin usein siitä, mitä mittaria kulloinkin käytetään (Glück 2019). Clayton ja Birren (1980) sekä Ardelt (1997) käyttivät viisauden tutkimisessa kolmiportaista mallia, jonka mukaan viisautta on vain, jos kaikkien sen mittaamiseen käytettävien kognitiivisten, reflektiivisten ja affektiivisten mittarien mukaan ihminen on viisas. Ihminen voi täten olla erikseen esimerkiksi älykäs olematta viisas (ks. esim. Sternberg 2019b). Tässä tutkimuksessa käsittelin viisautta erillisinä piirteinä,joiden yhteyttä toisiinsa ei mitattu. Siksi mielestäni puhtaasti viisaudesta puhuminen tutkimukseni aineiston perusteella ei ole vielä perusteltua. Tästä syystä tyydynkin vielä puhumaan viisauden piirteistä viisauden sijasta.

Haastatteluissa ei myöskään simuloitu fiktiivisiä elämän eri tilanteiden ongelmia, joihin haastateltava olisi etsinyt pohdintansa avulla ratkaisua, kuten berliiniläistä viisauden paradigmaa hyödyntäneissä Baltesin ja Smithin (1990), Takkisen ym. (1999) sekä Grossmannin (2017) tutkimuksissa. Täten keskusteleminen pelkästään mediasuhteeseen liittyvistä asioista ei välttämättä ilmennä viisautta luotettavimmalla tavalla. Jatkossa olisikin mielenkiintoista tutkia syvempien ongelmallisten mediaan liittyvien fiktiivisten tapausten kautta ikäihmisten viisautta. Tällöin kyseeseen tulisi vielä selkeämmin yleinen viisaus (ks. mm. Staudinger 2013).

Sternberg (1990) muistuttaa, että viisauden piirteiden luokittelu ei tee oikeutta viisauden tutkimukselle sen kompleksisen luonteen takia. Tässä tutkimuksessa on käytetty kategorisoimista hyväksi ja uskon, että vaikka viisautta hieman yksinkertaistettiin tiettyyn muottiin, haastattelutilanteet olivat oiva keino päästä käsiksi kohteiden pohdintaan heidän mediasuhteensa muovautumisesta elämänkulun aikana. Viisaus on myös asia, jonka ilmenemisen seuraukset saatetaan voida todentaa vas- ta myöhemmin tulevaisuudessa (Yang 2013). Tulkintaani ohjasi tutkimuskirjallisuuden perusteella muodostettu viisauden piirteiden kehikko, joka todennäköisesti on saanut minut tutkijana näkemään viisautta haastateltavien mediasuhteissa enemmän kuin siellä muiden silmin saattaisi sitä olla. Pidin kuitenkin analysoidessani mielessäni, mihin viisauden piirteeseen löydökset olivat palautettavissa. Siten määritelmät eivät päässeet kokonaan katoamaan tulkinnan pohjalta.

On kuitenkin otettava huomioon, että muodostamani viisauden piirteiden kehikko on luotu kategorisoimalla tarkkoja piirteitä laajempiin raameihin osittain tulkiten sitä, mitä alkuperäisessä tekstissä on sanottu. Esimerkiksi osa tutkijoista (Csikzentmihalyi \& Rathunde 1990; Glück \& Bluck 2013) on maininnut yhden viisauteen liittyvistä komponenteista olevan empatia. Kuitenkin Empatia ja muista välittäminen -kategorian pohjana on myös piirteitä kuten pyrkiminen eri rybmiä byödyttävään ratkaisuun (Ruoppila 2013) tai kaikkien elämän parantamisen tavoittelu (Yang 2013) (liite 1), jolloin tarkempia määritelmiä on hieman pakotettu empatian ja muista välittämisen raameihin. Täten siis tutkimuksen kontekstiin sovellettua teoriaa on jouduttu hieman tulkitsemaan jo ennen varsinaista aineiston tulkintaa. Tutkimuksessani käytetyt viisauden piirteet ovat kuitenkin yhteneväisiä viisauden tutkimuksiin liittyneiden meta-analyysien kanssa ainakin empatian, myötätunnon, reflektion, itsensä ymmärtämisen, epätietoisuuden, avoimuuden sekä tunteiden säätelyn osalta (Meeks \& Jeste 2009; Bangen ym. 2013). Näiltä osin käyttämäni viisauden piirteet ovat luotettavia ainakin erillisinä komponentteina.

Vaikka olisi liian aikaista puhua viisaudesta ikäihmisten mediasuhteissa, on selvää, että tutkimukseni avulla tiedämme enemmän ikäihmisten mediasuhteista ja niissä esiintyvästä toiminnasta, kuten kriittisestä suhtautumisesta, neuvojen antamisesta, kokemuksen hyödyntämisestä, digitalisaation tuomasta huolesta sekä 
osaamisesta ja ennakkoluulottomasta asenteesta uutta kohtaan. Siten onkin perusteltua sanoa, että joidenkin ikäihmisten on mahdollista osoittaa viisauden piirteitä mediasuhteissaan.

\section{Yhteydenotto}

\section{Timo Cornér, KM}

Kasvatustieteiden tiedekunta, Lapin yliopisto tcorner@ulapland.fi

\section{Kirjallisuus}

Ardelt, M. (1997). Wisdom and life satisfaction in old age. Journal of Gerontology, 52B, 15-27.

Ardelt, M., Pridgen, S., \& Nutter-Pridgen, K. L. (2019). Wisdom as personality type. Teoksessa Sternberg, R. J. \& Glück, J. (toim.), The Cambridge Handbook of Wisdom (s. 144-161). New York: Cambridge University Press.

Arlin, P. K. (1990). Wisdom: the art of problem finding. Teoksessa Sternberg, R. J. (toim.), Wisdom: Its nature, origins, and development (s. 230-243). New York: Cambridge University Press.

Baltes, P.B. \& Smith, J. (1990). Toward a psychology of wisdom and its ontogenesis. Teoksessa Sternberg, R.J. (toim.), Wisdom: Its nature, origins, and development (s. 87-120). New York: Cambridge University Press.

Baltes, P. B. \& Staudinger, U. M. (2000). Wisdom, a metaheuristic to orchestrate mind and virtue towards excellence. American Psychologist, 55, 122136. doi: 10.1037//0003-066x.55.1.122.

Bangen, K. J., Meeks, T. W. \& Jeste, D. V. (2013). Defining and assessing wisdom: a review of the literature. The American Journal of Geriatric Psychiatry, 21(12), 1254-1266. doi: 10.1016/j.jagp.2012.11.020.

Barrett, E. A., Raphael, A. \& Gunderson, J. (2014). Reflections of old age, constructions of aging selves: Drawing links between media images and views of aging. Teoksessa Harrington, L .C, Bielby, D. \& Bardo, A.R. (toim.), Aging, media and culture. (s. 39-50). London: Lexington Books.

Blackwell, D., Leaman, C., Tramposch, R., Osborne, C. \& Liss, M. (2017). Extraversion, neurotism, attachment style and fear of missing out as predictors of social media use and addiction. Personality and Individual Differences, 116, 69-72. https://doi.org/10.1016/j.paid.2017.04.039
Bluck, S. \& Glück, J. (2004). Making things better and learning a lesson: experiencing wisdom across the lifespan. Journal of Personality, 72 (3), 543-572. https://doi.org/10.1111/j.00223506.2004.00272.x.

Bolin, G. (2013). Age, generation and the media. Northern Lights, 11(1), 3-14.

Buckingham, D. (2003). Media education: Literacy, learning, and contemporary culture. Cambridge, UK: Polity Press.

Cambridge Dictionary: Empathy. Haettu 8.11.2019 osoitteesta https://dictionary.cambridge.org/dictionary/english/empathy.

Castilla D., Botella C., Miralles I., Breton-Lopez, J., Dragomir-Davis, A-M., Zaragosa, I. \& Garcia-Palacios, A. (2018). Teaching digital literacy skills to the elderly using a social network with linear navigation: A case study in a rural area. International Journal of Human-Computer Studies, 118, 24-37. https://doi.org/10.1016/j.ijhcs.2018.05.009.

Christensen, C. L. \& Petersen, L. N. (2017) Introduction. Nordicom Review, 38 (1), 3-7. doi: 10.1515/nor-2017-0399.

Clayton, V.P. \& Birren,J.E. (1980). The development of wisdom across the life span: a reexamination of an ancient topic. Teoksessa Baltes, P. B. \& Brim, Jr. O. G. (toim.), Life-span development and behavior (s. 104-135). New York: Academic Press.

Cohler, B. J. \& Hostetler, A. (2003). Linking life course and life story. Teoksessa Mortimer, J. T. \& Shanahan, M. J. (toim.), Handbook of the life course (s. 555-578). New York: Kluwer Academicl Plenum Publishers.

Cooney, T. M. \& Curl, A. L. (2019). Transitioning from successful aging: A life course approach. Journal of Aging and Health, 31 (3), 528-551. https://doi.org/10.1177/0898264317737892.

Csikszentmihalyi, M. \& Rathunde, K. (1990). The psychology of wisdom: An evolutionary interpretation. Teoksessa Sternberg, R.J. (toim.), Wisdom: Its nature, origins, and development (s. 25-51). New York: Cambridge University Press.

van Deursen, Alexander J. A. M. \& Helsper, E. J. (2015). A nuanced understanding of Internet use and non-use among the elderly. European Journal of Communication, 30 (2), 171-187.

Elder, G. H. (1994). Time, human agency, and social change: Perspectives on the life course. Social Psychology Quarterly, 57 (1), 4-15. 
Elder, G. H., Johnson, M. K. \& Crosnoe, R. (2003). The emergence and development of life course theory. Teoksessa Mortimer, J. T. \& Shanahan, M. J. (toim.), Handbook of the life course (s. 3-22). New York: Kluwer Academic/Plenum Publishers.

Elliot, A. J., Mooney, C. J., Douthit, K. Z. \& Lynch, M. F. (2014). Predictors of older adults' technology use and its relationship to depressive symptoms and well-being. The Journals of Gerontology Series B: Psychological Sciences and Social Sciences, 69, 667-677. https://doi.org/10.1093/geronb/gbt109.

English, T. \& Carstensen, L. L. (2014). Selective narrowing of social networks across adulthood is associated with improved emotional experience in daily life. International Journal of Behavioral Development, 38, 195-202. doi:10.1177/0165025413515404.

Erikson, E. H. (1959). Identity and the life cycle: Selected papers. New York: International Universities Press.

Flick, U. (2002). An introduction to qualitative research. London: Sage.

Fortunati, L. (2014). Media between power and empowerment. Can we resolve this dilemma? The Information Society: An International Journal, 30 (3), 169-183. https://doi.org/10.1080/01972243.2014.896676.

Fried, S. \& Haarni, I. (2017). Keskusteluja: Ikääntyvien elämäntaidoissa kiteytyy elämänkokemuksen moni-ilmeisyys. Gerontologia, 31 (2),133-141.

Friemel, T. N. (2016). The digital divide has grown old: Determinants of a digital divide among seniors. New Media E Society, 18 (2), 313-331. https://doi.org/10.1177/1461444814538648.

Giskov, C. (2017). Growing old with mediatization. Nordicom Review, 38 (1), 53-64. doi:10.1515/nor-2017-0402.

Glück, J. (2019). The Development of Wisdom during Adulthood. Teoksessa Sternberg, R. J. \& Glück, J. (toim.), The Cambridge Handbook of Wisdom (s. 323-346). New York: Cambridge University Press.

Glück, J. \& Bluck, S. (2013). The MORE life experience model: A theory of the development of personal wisdom. Teoksessa Ferrari, M. \& Weststrate, N. M. (toim.), The scientific study of personal wisdom. From contemplative studies to neuroscience (s. 75-97). Dordrecht, Heidelberg, New York, London: Springer.
Grossmann, I. (2017). Wisdom in context. Perspectives on Psychological Science, 12 (2), 233-257. https://doi.org/10.1177/1745691616672066.

Grossmann, I., Kung, F. Y. H. \& Santos, H. C. (2019). Wisdom as state versus trait. Teoksessa Sternberg, R. J. \& Glück, J. (toim.), The Cambridge Handbook of Wisdom (s. 249-274). New York: Cambridge University Press.

Guess, A., Nagler, J. \& Tucker, J. (2019). Less than you think: Prevalence and predictors of fake news dissemination on Facebook. Science Advances, 5 (1), 1-8. doi:10.1126/sciadv.aau4586.

Haddon, L. (2018). Generational analysis of people's experience of ICTs. Teoksessa Taipale, S., Wilska, T-A. \& Gilleard, C. (toim.), Digital technologies and generational identity (s. 37-51). London, UK: Routledge.

Hakkarainen, P. (2009). Mediaelämänkerta kertoo mediasuhteista ja sosiaalisista suhteista. Teoksessa Hakkarainen, P. \& Vaattovaara, V. (toim.), Minun mediani. Opiskelijoiden kertomuksia mediasubteista (s. 13-26). Rovaniemi: University of Lapland, Faculty of Education.

Hakkarainen, P. (2012). "No good for shovelling snow and carrying firewood" - Social representations of computers and the Internet by elderly Finnish non-users. New Media E Society, 14 (7), 1198-1215. https://doi.org/10.1177/1461444812442663.

Hall, G. S. (1922). Senescence: The last half of life. New York: Appleton.

Heikkinen, E., Jyrkämä, J. \& Rantanen, T. (toim.) (2013). Gerontologia 3. Helsinki: Duodecim.

Helsper, E. J. \& Reisdorf, B. C. (2013). Quantitative examination of explanations for reasons of internet non-use. Cyberpsychology, Behavior, and Social Networking, (16) 2, 94-99. https://doi.org/10.1089/cyber.2012.0257.

Hepp, A., Berg, M. \& Roitch, C. (2017). A Processual Concept of Media Generation. The mediagenerational positioning of elderly people. Nordicom Review, 38 (1), 109-122. doi:10.1515/nor-2017-0395.

Holliday, S. G. \& Chandler, M. J. (1986). Wisdom: Explorations in adult competence. New York: Karger.

Kielitoimiston sanakirja: Empatia. Haettu 8.11.2019 osoitteesta https://www.kielitoimistonsanakirja. fi/.

Kitchener, K. S. \& Brennen, H. G. (1990). Wisdom and reflective judgement: knowing in the 
fact of uncertainty. Teoksessa Sternberg, R. J. (toim.), Wisdom: Its nature, origins, and development (s. 212-229). New York: Cambridge University Press.

Kivimäki, S. (2017). Ikää ihmettelemässä. Lähikuva 3, 62-77.

Kotilainen, S. (2009). Suhteet mediaan - Avainkokemuksia nykykulttuurissa. Teoksessa Kotilainen, S. (toim.), Subteissa mediaan. Nykykulttuurin tutkimuskeskuksen julkaisuja 99 (s. 7-18). Jyväskylä: Jyväskylän yliopisto.

Kramer, D. A. (1990). Conceptualizing wisdom: the primacy of affect-cognition relations. Teoksessa Sternberg, R.J. (toim.), Wisdom: Its nature, origins, and development (s. 279-316). New York: Cambridge University Press.

Kuoppamäki, S. (2018). The role of age and life course stage in digital consumption. JYU Dissertations 36. Jyväskylä: Jyväskylän yliopisto.

Kupiainen, R. (2009). Lasten mediasuhteet mediakasvatuksen kysymyksenä. Teoksessa Kotilainen, S. (toim.), Subteissa mediaan. Nykykulttuurin tutkimuskeskuksen julkaisuja 99 (s. 167-184). Jyväskylä: University of Jyväskylä.

Kämpfen, F. \& Maurer,J. (2018).Does education help "old dogs" learn "new tricks"? The lasting impact of early-life education on technology use among older adults. Research Policy, 47 (6), 1125-1132. https://doi.org/10.1016/j.respol.2018.03.017.

Labouvie-Vief, G. (1990). Wisdom as integrated thought: historical and developmental perspectives. Teoksessa Sternberg, R.J. (toim.), Wisdom: Its nature, origins, and development (s. 52-86). New York: Cambridge University Press.

Markkola, P. (2015). Kielen päällä: Vanhuus ja viisaus. Gerontologia, 29 (3), 214-216.

Meeks, T. W. \& Jeste, D. V. (2009). Neurobiology of wisdom: a literature overview. Arch Gen Psychiatry, 66 (4), 355-365. doi:10.1001/archgenpsychiatry.2009.8.

Montgomery, A., Barber, C. \& McKee, P. (2002). A phenomenological study of wisdom in later life. International Journal of Aging and Human Development, 52, 139-157.

Murumaa-Mengel, M. \& Siibak, A. (2019). Compelled to be an outsider: How students on a social media detox self-construct their generation. Teoksessa Bolin, G. \& Colombo, F. (toim.), Special edition: Generations, Time, and Media. Comunicazioni Sociali, Journal of Media, Performing Arts and Cultural Studies, 2, 263-275.
Naab, T. \& Schwartzenegger, C. (2017). Why aging is more important than being old. Nordicom Review, 38 (1), 93-107. https://doi.org/10.1515/nor-2017-0400.

Oakes, H., Brienza, J. P., Elnakouri, A., Grossmann, I. (2019). Wise reasoning: Converging evidence for the psychology of sound judgement. Teoksessa Sternberg, R.J. \& Glück, J. (toim.), The Cambridge Handbook of Wisdom (s. 202-225). New York: Cambridge University Press.

Ofcom. (2019). Adults' media use and attitudes report 2019. Lontoo: Ofcom. Haettu 23.10.2019 osoitteesta https://www.ofcom.org.uk/research-and-data/media-literacy-research/adults/ adults-media-use-and-attitudes.

Orwoll, L. \& Perlmutter, M. (1990). The study of wise persons: integrating a personality perspective. Teoksessa Sternberg, R. J. (toim.), Wisdom: Its nature, origins, and development (s. 160-180). New York: Cambridge University Press.

Pendergast, D. \& Garattini, C. (2015). Critical reflections on ageing and technology in the twenty-first century. Teoksessa Pendergast, D. \& Garattini, C. (toim.), Aging and the digital life course (s. 1-15). New York: Berghan Books.

Pillemer, K. A. (2011). 30 Lessons for living: Tried and true advice from the wisest Americans. New York: Penguin Group.

Prensky, M. (2001). Digital natives, digital immigrants. On the Horizon, 9 (5), 1-6.

Rasi, P. (2018). Internet nonusers. Teoksessa Warf, B. (toim.), The SAGE encyclopedia of the internet, 2 (s. 532-539). Thousand Oaks, CA: Sage Publications Ltd.

Rasi, P. \& Kilpeläinen, A. (2015). The digital competences and agency of older people living in rural villages in Finnish Lapland. International Journal of Media, Technology E Lifelong Learning, 11 (2), 149-160.

Rasi, P. \& O'Neil, C. (2014). Dinosaurs and fossils living without dangerous tools: Social representations of computers and the Internet by elderly Finnish and American non-users. Seminar.net. International Journal of Media, Technology \& Lifelong Learning, 10 (1), 55-72.

Rhoda, J. C. (2010). Individual resistance to IT innovations. Communications of the ACM, 53 (4), 144146. doi:10.1145/1721654.1721693.

Ruoppila, I. (2013).Viisaus. Teoksessa Heikkinen, E., Jyrkämä, J. \& Rantanen, T. (toim.), Gerontologia 3. (s. 227-236). Helsinki: Duodecim. 
Selwyn, N. (2006). Digital division or digital decision? A study of non-users and low-users of computers. Poetics, 34 (4-5), 273-292. https://doi.org/10.1016/j.poetic.2006.05.003.

Seppänen, J. \& Väliverronen, E. (2013) Mediayhteiskunta. 2. painos. Tampere: Vastapaino.

Sims, T., Reed, A. E. \& Carr, D. C. (2017). Information and communication technology use is related to higher well-being among the oldest-old. The Journals of Gerontology: Series B, 72 (5), 761770. doi:10.1093/geronb/gbw130.

Staudinger, U. (2013). The need to distinguish personal from general wisdom: A short history and empirical evidence. Teoksessa Ferrari, M. \& Weststrate, N. M. (toim.), The scientific study of personal wisdom. From contemplative studies to neuroscience (s. 3-20). Dordrecht, Heidelberg, New York, London: Springer.

Staudinger, U. M. \& Glück, J. (2011). Psychological wisdom research: commonalities and differences in a growing field. Annual Review of Psycholo$g y, 62,215-241$.

Sternberg, R. J. (1990). Wisdom and its relations to intelligence and creativity. Teoksessa Sternberg, R. J. (toim.), Wisdom: Its nature, origins, and development (s. 142-159). New York: Cambridge University Press.

Sternberg, R. J. (1998). A balance theory of wisdom. Review of General Psychology, 2 (4), 347-365.

Sternberg R. J. (2004). What is wisdom and how can we develop it? The ANNALS of the American Academy of Political and Social Science, 591 (1), 164-174.

Sternberg, R. J. (2013). Personal wisdom in the balance. Teoksessa Ferrari, M. \& Weststrate, N. M. (toim.), The scientific study of personal wisdom. From contemplative studies to neuroscience (s. 5374). Dordrecht, Heidelberg, New York, London: Springer.

Sternberg, R. J. (2019a). Race to Samarra: The Critical importance of Wisdom in the World Today. Teoksessa Sternberg, R.J. \& Glück, J. (toim.), The Cambridge Handbook of Wisdom (s. 3-9). New York: Cambridge University Press.

Sternberg, R. J. (2019b). Why People Often Prefer Wise Guys to Guys Who Are Wise: An Aug- mented Balance Theory of the Production and Reception of Wisdom. Teoksessa Sternberg, R. J. \& Glück, J. (toim.), The Cambridge Handbook of Wisdom (s. 162-81). New York: Cambridge University Press.

Taipale, S. \&Hänninen, R. (2018). More years, more technologies: Aging in the digital era. Human technology, 14 (3), 258-263.

https://doi.org/10.17011/ht/urn.201811224832.

Takkinen, S., Pakarinen, E., Aunola, K., Männikkö, K. \& Ruoppila, I. (1999). Viisaustestin toimivuus suomalaisten iäkkäiden henkilöiden haastattelututkimuksessa. Gerontologia, 13 (1), 22-32.

Tilastokeskus. (2017). Vapaa-ajan osallistuminen. Haettu 23.10.2019 osoitteesta http://www.stat.fi/til/vpa/index.html.

Tilastokeskus. (2018). Väestön tieto- ja viestintätekniikan käyttö. Haettu 9.9.2019 osoitteesta: http://www.stat.fi/til/sutivi/index_en.html

Ting, C. (2014). The role of awareness in Internet non-use: experiences from rural China. Information Development, 32 (3), 327-337. https://doi.org/10.1177/0266666914550425.

Webster, J. D. (2007). Measuring the character strength of wisdom. Aging and Human Development, 65 (2), 163-183. https://doi.org/10.2190/AG.65.2.d.

Wikisanakirja, vapaa sanakirja: tietotyöläinen. Haettu 5.3.2020 osoitteesta: https://fi.wiktionary.org/ wiki/tietoty\%C3\%B61\%C3\%A4inen.

Yang, S. Y. (2013). From personal striving to positive influence: Exploring wisdom in real-life contexts. Teoksessa Ferrari, M. \& Weststrate, N. M. (toim.), The scientific study of personal wisdom. From contemplative studies to neuroscience (s. 115136). Dordrecht, Heidelberg, New York, London: Springer. Haettu 8.9.2019 osoitteesta: https://link.springer.com/content/pdf/10.1007\%2F978-94-007-7987-7.pdf.

Yang, S-Y. \& Intezari, A. (2019). Non-western lay conceptions of wisdom. Teoksessa Sternberg, R.J. \& Glück, J. (toim.), The Cambridge Handbook of Wisdom (s. 429-452). New York: Cambridge University Press. 


\section{Liite 1. Eri tutkijoiden käsityksiä viisaudesta ja sen osa-alueista}

Clayton \& Birren 1980; Ardelt 1997: älykkyys, looginen ajattelu, objektiivisuus, keskittymiskyky, ongelmien ytimen näkeminen

Holliday \& Chandler 1986: hyvä arvostelukyky, hyvien neuvojen antaminen, itsensä ymmärtäminen, asioiden näkeminen suuressa mittakaavassa

Arlin 1990: laaja tietopohja, avoimuus muutokselle, kysymysten esittäminen, ongelmien löytäminen

Baltes \& Smith 1990; Takkinen ym. 1999: faktatietous ja menettelytapatietämys, ohjeiden antaminen tärkeissä kysymyksissä, epävarmuuden havaitseminen ja sieto, elämänkulun kontekstuaalisuuden huomioon ottaminen

Csikzentmihalyi \& Rathunde 1990: älykkyys, ristiriitaisten tietojen kanssa tasapainoilu tavoitteellisesti, empaattisuus

Kitchener \& Brennen 1990: vastakkaisten näkemysten yhdisteleminen tietopohjan kehittämisessä, tietämisen epävarman luonteen tunnustaminen, sensitiivisyys asiayhteyksille

Kramer 1990:yksilöllisyyden tunnistaminen, muiden neuvominen, muutoksen ymmärtäminen, kognition ja vaikuttamisen yhdistäminen tilanteeseen sopivalla tavalla, omien ongelmien ratkaiseminen, sosiaalisten tilanteiden hallitseminen

Labouvie-Vief 1990: reflektion ja kriittisen ajattelun yhdistäminen

Orwoll \& Perlmutter 1990: itsekkyyden ylittäminen, korkealle kehittynyt persoonallisuus, omien rajojen tiedostaminen

Sternberg 1990, 1998, 2004, 2013, 2019: tarkkanäköisyys, älykkyyden ja luovuuden yhdisteleminen, hyvä järkeilykyky, muiden ja omien etujen välillä tasapainoilu, ratkaisun tekeminen tilanteeseen sopivalla tavalla, kokemuksen soveltaminen, olosuhteisiin mukautuminen ja niiden muokkaaminen, eettisyys

Montgomery, Barber \& McKee 2002: tietämys, myötätuntoisuus ihmissuhteissa, opastaminen, kokemus, moraalinen periaatteellisuus
Bluck \& Glück 2004: sisäisten ja ulkoisten paineiden vastustuskyky, tasapainon tavoittelu ongelmanratkaisussa, yllättävien ja paradoksaalisten ongelmien ratkaiseminen, eettisesti kestävien ratkaisujen tekeminen

Webster 2007: reflektointi, muistelu, tunteiden säätely, avoimuus, kriittinen elämänkokemus, huumorin hyödyntäminen

Meeks \& Jeste 2009; Bangen, Meeks \& Jeste 2013: elämän tuntemus, reflektoiminen, prososiaaliset arvot ja muiden arvojen hyväksyminen, itsensä ymmärtäminen, tunteiden tasapainottaminen, epävarmuuden tunnustaminen, avoimuus, huumorintaju

Glück \& Bluck 2013: reflektoiminen, empatia, tietous omista rajoista ja vahvuuksista, avoimuus, oppiminen elämän kokemuksista, tunteiden säätely tilanteeseen sopivalla tavalla

Ruoppila 2013: kokemukseen liitännäinen syvä ja selkeä ajattelu, eri ryhmiä hyödyttäviin tasapainoisiin ja eettisiin ratkaisuihin pyrkiminen, epävarmuuden sietäminen

Staudinger 2013: neuvojen antaminen, elämän merkityksellisyyden ymmärtäminen, omien kykyjen, tunteiden ja tavoitteiden ymmärtäminen, muiden ongelmien ratkaisemiseksi tarjottu apu

Yang 2013: hiljainen tieto, kaikkien elämän parantamisen tavoittelu

Markkola 2015: vastoinkäymisten jättäminen taakse, pikkuasioihin takertumattomuus, oman elämän taidokas jäsentely

Grossmann, Kung \& Santos 2019: itsensä näkeminen osana muiden ihmisten muodostamaa kokonaisuutta, tunnerikas ja/tai tunteilla tasapainotettu elämä

Oakes, Brienza, Elnakouri \& Grosmann 2019: älyllinen nöyryys, näkökulmien yhdistely, muiden ihmisten näkökulmien ymmärtämiseen pyrkiminen, epävarmuuden ja muutoksen tunnistaminen

Weststrate, Bluck \& Glück 2019: psykologisten ominaisuuksien mukauttaminen tilanteisiin 